\title{
A comprehensive review on avian chlamydiosis: a neglected zoonotic disease
}

\author{
Karthikeyan Ravichandran ${ }^{1}$ (D) Subbaiyan Anbazhagan ${ }^{2} \cdot$ Kumaragurubaran Karthik $^{3} \cdot$ Madesh Angappan $^{1}$. \\ Balusamy Dhayananth ${ }^{1}$
}

Received: 12 November 2020 / Accepted: 9 July 2021 / Published online: 27 July 2021

(c) The Author(s), under exclusive licence to Springer Nature B.V. 2021

\begin{abstract}
Avian chlamydiosis is one of the important neglected diseases with critical zoonotic potential. Chlamydia psittaci, the causative agent, affects most categories of birds, livestock, companion animals, and humans. It has many obscured characters and epidemiological dimensions, which makes it unique among other bacterial agents. Recent reports on transmission from equine to humans alarmed the public health authorities, and it necessitates the importance of routine screening of this infectious disease. High prevalence of spill-over infection in equines was associated with reproductive losses. Newer avian chlamydial species are being reported in the recent years. It is a potential biological warfare agent and the disease is an occupational hazard mainly to custom officers handling exotic birds. Prevalence of the disease in wild birds, pet birds, and poultry causes economic losses to the poultry industry and the pet bird trade. Interestingly, there are speculations on the 'legal' and 'illegal' bird trade that may be the global source of some of the most virulent strains of this pathogen. The mortality rate generally ranges from 5 to $40 \%$ in untreated cases, but it can sometimes be higher in co-infection. The intracellular lifestyle of this pathogen makes the diagnosis more complicated and there is also lack of accurate diagnostics. Resistance to antibiotics is reported only in some pathogens of the Chlamydiaceae family, but routine screening may assess the actual situation in all pathogens. Due to the diverse nature of the pathogen, the organism necessitates the One Health partnerships to have complete understanding. The present review focuses on the zoonotic aspects of avian chlamydiosis with its new insights into the pathogenesis, transmission, treatment, prevention, and control strategies. The review also briefs on the basic understandings and complex epidemiology of avian chlamydiosis, highlighting the need for research on emerging one health perspectives.
\end{abstract}

Keywords Avian chlamydiosis · Chlamydia psittaci $\cdot$ Elementary body $\cdot$ Equine chlamydiosis $\cdot$ MOMP $\cdot$ One Health $\cdot$ Ornithosis $\cdot$ Psittacosis $\cdot$ Psittacine

\section{Introduction}

Neglected zoonotic diseases (NZDs) are a strenuous challenge for the scientific community because of their complex biology, transmission, and ability to cause infection in multiple host species. Avian chlamydiosis is one among the NZD and pet bird lovers should be aware that it could cause

Karthikeyan Ravichandran

karthi6162@gmail.com

1 Division of Public Health and Epidemiology, ICAR-Indian Veterinary Research Institute, Izatnagar, India

2 Division of Bacteriology and Mycology, ICAR-Indian Veterinary Research Institute, Izatnagar, India

3 Central University Laboratory, Tamil Nadu Veterinary and Animal Sciences University, Chennai, India dangerous atypical pneumonia in humans (European Commission 2002). The pathogen is capable of causing spill-over infection in humans from the birds (Jenkins et al. 2018). The importation of exotic pet birds resulted in the easy spread of avian chlamydiosis. The causative agent of avian chlamydiosis is Chlamydia psittaci (also known as Chlamydophila psittaci (later reunited)), and the infection in humans is named ornithosis/psittacosis/parrot fever/chlamydiosis. The term ornithosis was coined by Dr. Karl Friedrich Meyer (renowned for his work in Chlamydial organisms) (Ramsay 2003). Birds (poultry, pet birds, wild birds) are the natural host, but other animals like cattle, goat, sheep, horse, pig, fox, and dog, including humans, can get the infection (Hogerwerf et al. 2020). The disease has been recognized for long as a serious threat to human health and a worldwide anthropozoonotic disease. Although it is an ancient disease 
described in 1615 by Fra Bartolomeo (Belmas 1714), still there is no accurate diagnostic technique due to the intracellular nature of the pathogen. Recent advancements in culture-independent genomic studies increased knowledge and expanded the diversity of this pathogen. Currently, there are multiple reports of new and unexpected cases of chlamydia associated with community-acquired pneumonia (CAP) around the world which highlighted the importance of multi-disciplinary 'One Health' collaboration to tackle this pathogen. Around 1\% of CAP worldwide is caused by C. psittaci (Hogerwerf et al. 2017).

Psittakos: Greek word: parrot. Ornis: Greek word: Hen. Chlamys: Greek word: mantle.

\section{History}

Avian chlamydiosis has a long history from the nineteenth century (1879) when Dr. Jakob Ritter, a Swiss physician first reported psittacosis in humans. He related an epidemic of fatal respiratory disease in humans that might be due to contact with caged parrots and finches (Ritter 1879). The name 'Psittacosis' was given when a flu-like infection was transmitted from birds to humans in 1893 (Morange 1895). Initially, it was suspected as a disease of viral origin. In 1893 , Edmond Nocard isolated a Gram-negative bacterium from the bone marrow of parrots dying of psittacosis (Bacillus psittacosis). Later in the year 1929-1930, the first pandemic of psittacosis in human being occurred in many countries in Europe and North and South America (more than 700 human cases worldwide) (Ramsay 2003) due to the shipment of Green Amazon parrot from Argentina and the pathogen in human was first identified by Bedson et al. (1930). Levinthal, Coles, and Lillie in 1930 described filterable bodies which are small, present in blood and tissue samples from infected birds and human patients, and in recognition of the fact they were called 'Levinthal-Coles-Lillie' (L.C.L.) bodies (Bedson et al. 1930; Meyer and Eddie 1933). Samuel P. Bedson and his co-worker J.O.W. Bland, in 1932 recognized and described for the first time the biphasic (initial body and elementary body) intracellular life cycle of psittacosis from an experiment in mice (Bedson and Bland 1932). In the same year, the first case of zoonotic psittacosis transmitted by a chicken was reported. Later during the period of 1931-1963 several countries, including India reported the occurrence of chlamydiosis. After the invention of electron microscopy in 1966, Chlamydiae were classified as bacteria as they own DNA, RNA, ribosomes, and a similar cell wall of Gram-negative bacteria (Matsumoto and Manire 1970; Harkinezhad et al. 2009). Later molecular diagnostic techniques were developed after the invention of polymerase chain reaction (PCR). Various outbreaks throughout the world generated much attention among researchers. Several years of research ultimately led to the characterization and description of the bacterium, Chlamydia psittaci. At present, $C$. psittaci has been contemplated as the classical pathogen with worldwide endemicity. For the past two decades, many reports across the world have been reported as small local outbreak clusters or as isolated cases (Ito et al. 2002; Berk et al. 2008; Gaede et al. 2008; Matsui et al. 2008; Sachse et al. 2015b; ArenasValls et al. 2017; Weygaerde et al. 2018).

\section{Aetiology, host, and transmission}

The taxonomic classification of the family Chlamydiaceae (order Chlamydiales, phylum Chlamydiae) with more than 15 distinct species are obligate intracellular, coccoid, gramnegative bacteria sharing a unique conserved biphasic life cycle in hosts (Pospischil 2009; Cheong et al. 2019; Arnaud and Van Wettere 2020). All the Chlamydial species will affect different hosts, but the disease pathology is highly similar. The chlamydia research community did not widely use the proposed subdivision of the genus into Chlamydia and Chlamydophila (based on $16 \mathrm{~S}$ and $23 \mathrm{~S}$ rRNA) because the organisms in the order Chlamydiales share $>80 \%$ of gene sequences based on 16S and 23S rRNA analysis (Everett et al. 1999a). The single genus of Chlamydia was adopted by the International Committee on the systematics of prokaryotes in the year 2010 (Greub 2010; Horn and Class 2010; Sachse et al. 2015a). The $C$. psittaci poses a single circular chromosome with a genomic size of $1.17 \mathrm{Mb}, \mathrm{GC} \%$ content 39.1\%, 1026 genes, and 973 proteins (Grinblat-Huse et al. 2011). The cell wall consists of lipopolysaccharides, Major Outer Membrane Protein (MOMP), and cysteine-rich proteins. The ompA gene, which codes for the MOMP, has four variable regions and five conserved regions (Fig. 1). C. psittaci is the primary causative agent with high zoonotic risk, and there are other species C. avium, C. gallinacea, C. ibidis (Candidatus taxon), C. buteonis identified in the recent past suggested the complex etiology of avian chlamydiosis (Table 1) (Vorimore et al. 2013; Sachse et al. 2014; Laroucau et al. 2019; Li et al. 2020). These species may not be the last chlamydial species to be identified in birds. Many studies documented various non-classified Chlamydiaceae species mainly from seabirds (Isaksson et al. 2015), pigeons, and ducks (Zocevic et al. 2013). Analysis of these newly identified species may increase the diversity probably far greater than currently conceived (Mitura et al. 2014; TaylorBrown and Polkinghorne 2017). C. gallinacea DNA was detected in whole blood samples, milk, faeces, and vaginal swabs in healthy dairy and beef cattle in China ( $\mathrm{Li}$ et al. 2016). This study suggested the possibility of transmission of Chlamydia sp. from birds to ruminants. C. gallinacea is a common pathogen in chickens and has the faecal-oral and vertical route of transmission among poultry (Guo et al. 


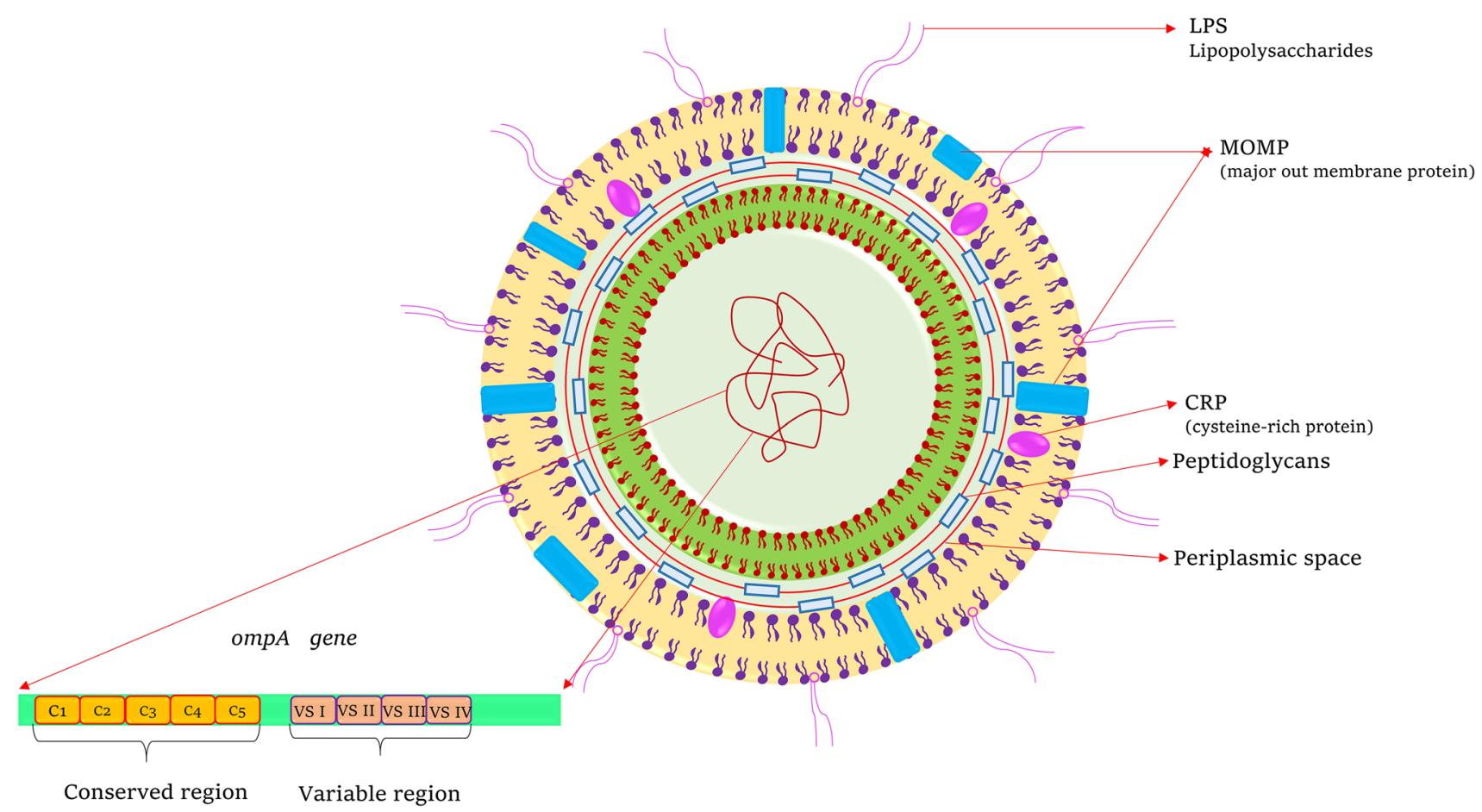

Fig. 1 Antigenic structure of C. psittaci

Table 1 Chlamydial species having birds as their primary hosts

\begin{tabular}{ll}
\hline Species & Primary hosts \\
\hline C. psittaci & Birds, mammals \\
C. avium & Pigeons, parrots, probably wild birds \\
C. gallinacea & Chickens, turkeys, guinea fowl, ducks, \\
& probably other poultry \\
C. ibidis & Feral African Sacred Ibis, Crested Ibis \\
C. buteonis & Red-shouldered hawk, buzzards \\
\hline
\end{tabular}

2016; You et al. 2019; Ornelas-Eusebio et al. 2020) and also documented to have the zoonotic potential ( $\mathrm{Li}$ et al. 2017). In France, atypical pneumonia incidences in slaughterhouse workers coincided with the isolation of $C$. gallinacea from infected domestic poultry (Laroucau et al. 2009a). Contrarily, the zoonotic potential of $C$. avium is unknown. The whole-genome sequence of $C$. avium showed the variation in virulence gene content, and further genomic studies are required for finding new insights into the virulence and evolution of this pathogen (Floriano et al. 2020). Five major types of analysis distinguish chlamydia species:

- $16 \mathrm{~S}$ and 23S rRNA full length,

- $r r n$ spacer (16S-23S intergenic spacer),

- $16 \mathrm{~S}$ and 23S ribosomal genes signature sequences (Everett et al. 1999b),
- RNase P RNA gene ( $r n p B$ ) encoding a ribonucleoprotein complex (Herrmann et al. 2000), and

- Outer membrane protein A (ompA) gene.

In the 1990s, the serotype classification of $C$. psittaci used monoclonal antibodies against the MOMP revealed aggregation of six avian (A-F) and two mammalians (WC in cattle and M56 in muskrat) serotypes and they have distinct host specificity. Different serotypes have been isolated from different avian species like serotype A in psittacine birds, $\mathrm{B}$ and $\mathrm{C}$ in both ducks and geese, D in turkeys, E mainly in pigeons (also in other avian species), and $\mathrm{F}$ in parakeets and turkeys. Serotype A is often reported in human zoonotic cases (Andersen 1991; Vanrompay et al. 1993). In recent times, genotypic classification is commonly used because of its convenience and rapidity. $C$. psittaci initially had several classical genotypes with relevant host specificity. The genomic sequence encoding the outer membrane protein $(o m p A)$ is used to classify genotypes, which are employed to study isolates from infected birds and isolates in mammals (Table 2) (Madani and Peighambari 2013; Hogerwerf et al. 2020). Some additional genotypes have been established in psittacine and wild birds later. All identified genotypes are considered capable of transmission to humans. The agent has been classified as a Category B pathogen by CDC due to its potential as a biological warfare agent, and it is a notifiable disease both in humans and birds (Rotz et al. 2002). 
Table 2 Genotype classification of Chlamydia psittaci and their hosts

\begin{tabular}{llc}
\hline Genotype (subgroups) & Endemic hosts & Other hosts \\
\hline A (A-VS1, A-6BC, A-8455) & Psittacine birds (Psittacidae) & $\begin{array}{l}\text { Turkeys, ducks, pigeons, and } \\
\text { Passeriformes }\end{array}$ \\
B & Pigeons & $\begin{array}{c}\text { Chickens, turkeys, ducks, } \\
\text { Psittacidae, and Passeri- } \\
\text { formes }\end{array}$ \\
& Wolumbiformes) & Chickens, ducks, and pigeons \\
C & Waterfowl (Anseriformes), such as ducks and geese & Pigeons, chickens \\
D(D-NJ1, D-9 N) & Turkeys & Turkeys, pigeons, ducks, \\
E, CAL-10, MP, OR MN & Humans & ostriches, and rheas \\
F & Belgian turkey farm \\
E/B (EB-E30, EB-859, EB- & Psittacine isolates VS225, prk \\
KKCP, & Daruma, 84/2334 (110), and 10,433-MA & Parrots, turkeys, and pigeons \\
M56 & Ducks & \\
WC & Outbreak in muskrats and hares & Outbreak of enteritis in cattle
\end{tabular}

The bacteria have a biphasic developmental cycle (Fig. 2) of 48-72 hours with four distinct morphological forms as an elementary body (EB), reticulate body (RB), intermediate body (IB), and the persistent aberrant body (AB). EB (size: $0.2 \mu \mathrm{m}$ ) are the infectious, non-replicating form, and present extracellular (Costerton et al. 1976). EB will survive in the environment for months due to its ability to resist drying. The RB (size: $0.8 \mu \mathrm{m}$ ) are fragile, non-infectious, intracellular form present in the reproductive stage, and also known as the initial body. During the transition between RB and EB, morphologically, IB can be noticed in the host cells. The RB will undergo persistence in stressed environmental conditions and termed as $\mathrm{AB}$ where it remains viable but non-infectious. Aberrant bodies accumulate chromosomes, but genes for cell division are no longer expressed until the stress-inducing factors like antibiotics, nutrient deprivation,

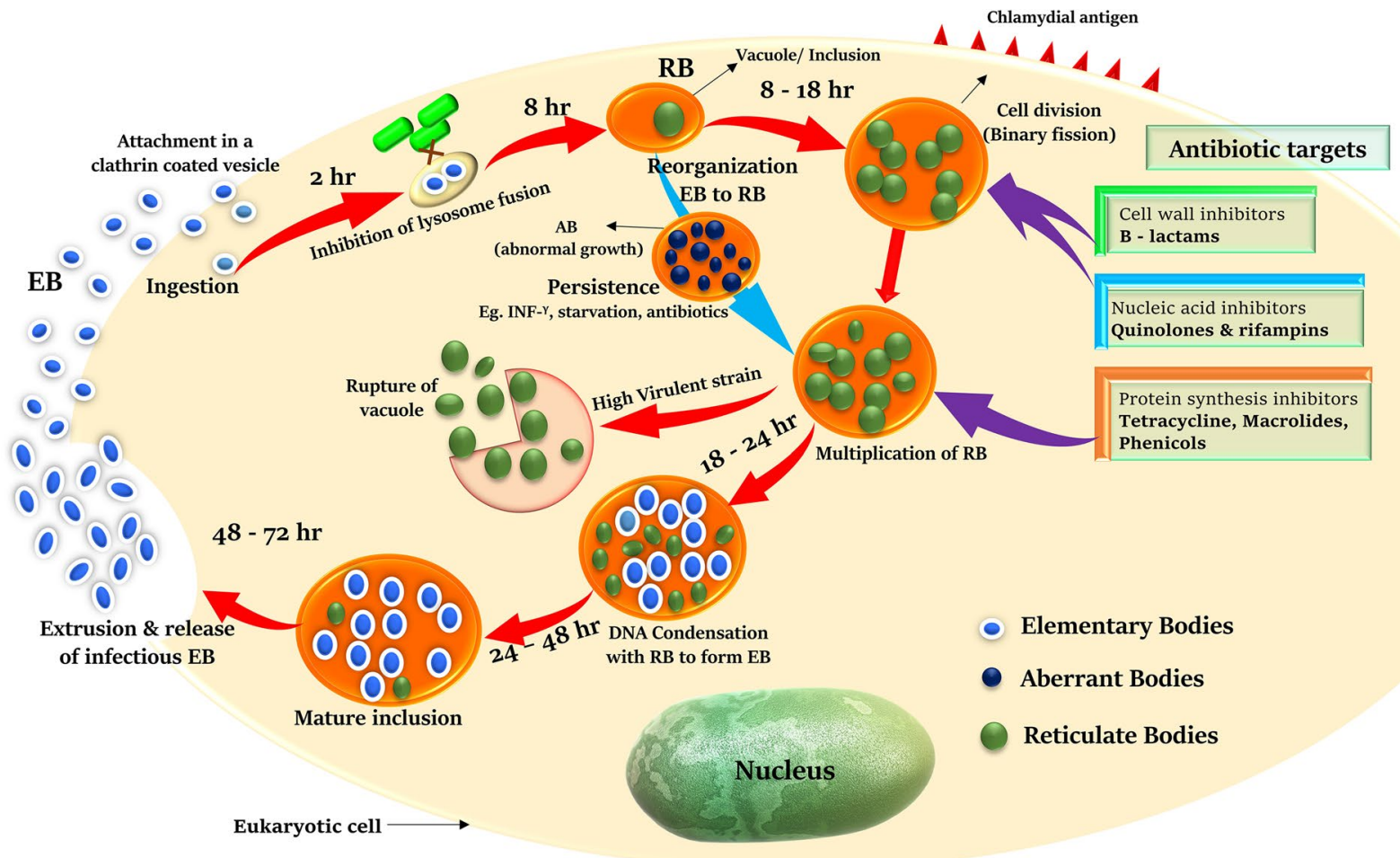

Fig. 2 Life cycle of chlamydia 
or immune factors-interferon-gamma (IFN- $\gamma$ ) in particular, are removed. It is being said that the type III secretion system plays an essential role in host-pathogen interaction.

Globally, C. psittaci was found in more than 500 avian species (belongs to 30 orders) of domestic, companion, wild, and free-living birds (Kaleta and Taday 2003; Knittler and Sachse 2015). The isolation of the bacteria was successfully carried out in more than 100 species of birds. Infection was found to be higher in pigeons and psittacine birds, and the bacteria could also affect 32 mammalian species. Avian species are the primary host and humans as an incidental/ accidental host for $C$. psittaci. Trans-ovarian transmission in birds has been reported. Human gets an infection through direct contact with plumage, and tissues of infected birds. Inhalation is another primary route of infection in humans and dried infective droppings, improper disposal of infected carcasses, aborted foetus or placenta, and secretions or dust from feathers are the source of infection. Intermittent shedding of the pathogen by carriers is an important reservoir for both birds and humans. Human infections are mostly reported from contact with psittacine birds, but there are reports of ornithosis in persons who worked in poultry, and slaughterhouses. The disease severity varies from unapparent to fatal in untreated patients (Vanrompay 2020).

\section{Avian chlamydiosis in birds and animals}

C. psittaci is capable of infecting all species of birds, but the range of susceptibility will vary. Other Chlamydial species like C. avium and C. gallinacea have a wide range of host specificity, but the $C$. ibidis and C. buteonis are host specific. The disease in birds is characterized by respiratory, digestive, or systemic infections. It can affect both wild and domestic birds worldwide with acute, subacute, or chronic forms. Among poultry, turkeys and ducks are more susceptible than chickens (Lin et al. 2019; Shivaprasad et al. 2015; Wang et al. 2018; Mattmann et al. 2019). Infected birds do not always exhibit signs of disease and latent infection is common in birds where intermittent or chronic disease with recurrent shedding can be noticed. Some strains are quiescent in birds, and infection occurs in favourable conditions. The severity of the infection will depend on the age and species of the bird; the type of chlamydial strain also plays a role. The disease incidence is captured frequently as a result of poor nutrition, overcrowding, and physiological stress. In birds, the bacteria infect both mucosal epithelial cells and macrophages of the respiratory tract. In domestic fowl, the infection causes both mortality and morbidity based on the virulence of the strain. Apart from poultry, chlamydiosis can cause serious economic losses in duck and turkey farming. Egg production may reduce by $10-20 \%$. International trade of pet birds could damage, if the PCR screening finds positive of $C$. psittaci because the test should be negative for 12 months period before the transport.

Birds can transmit the infection to their offspring by regurgitation, and it may cause a chronic form of chlamydiosis. The isolation of the pathogen from domestic birds like ducks and in companion birds like parrots pose them as a neglected reservoir and may act as a public health threat to large-scale poultry production. A systematic review on the zoonotic transmission of avian chlamydiosis revealed that more than Psittaciformes other poultry birds like ducks, chickens, and turkeys are having more substantial evidence for the source of human psittacosis (Hogerwerf et al. 2020). Symptoms in pet birds include lethargy, decreased appetite, ruffled feathers, ocular or nasal discharge, diarrhoea and/or green to yellow-green droppings and in post mortem identification splenomegaly with subscapular haemorrhages is a typical lesion, especially in psittacine birds. The symptoms are different based on strain and the host species and induce pericarditis, pneumonia, hepatitis, splenitis, and/or air sacculitis occasionally with fatal outcomes. In acute conditions, upper respiratory signs, lethargy, and green faeces will be noticed, and in chronic conditions, a sick unthrifty bird with a poor feather coat will be seen (Fig. 3). It has been said that bacteria may use the blood monocytes or macrophages as a porter to disseminate in the host body.

Prevalence of chlamydial organisms in wild birds has been reported from Poland with high positivity of $C$. psittaci (Krawiec et al. 2015). Many studies suggested the possibility of wildlife as a reservoir for chlamydial zoonosis. C. psittaci has been isolated from clinically normal livestock like cattle, goat, sheep, pigs, and rodents, showing their importance in reservoir and source of transmission (Radomski et al. 2016; Li et al. 2016; Taylor-Brown and Polkinghorne 2017). Feline pneumonitis caused by $C$. psittaci has also been reported. A polymerase chain reaction (PCR) targeting 16S rRNA with high-resolution melt (HRM) curve analysis revealed new chlamydial agents and the presence of $C$. psittaci in crocodiles (Robertson et al. 2010) and other reports in koalas, African clawed frogs (Vanrompay et al. 1995). The transmission of infection from non-avian domestic animals to humans is not proven so far. Chlamydial species like $C$. abortus, C. pneumoniae, and C. pecorium that affect mammals have not been reported from poultry.

\section{Avian chlamydiosis in humans}

The occurrence of ornithosis in humans depends on multiple factors like the intensity of exposure, microbial factors, and route of transmission (Rybarczyk et al. 2020). Highrisk groups include persons who work in poultry processing plants, pet shop employees, veterinarians, and bird owners who are having infected pet birds. Many zoonotic infections 
Fig. 3 Symptoms and clinical signs in birds

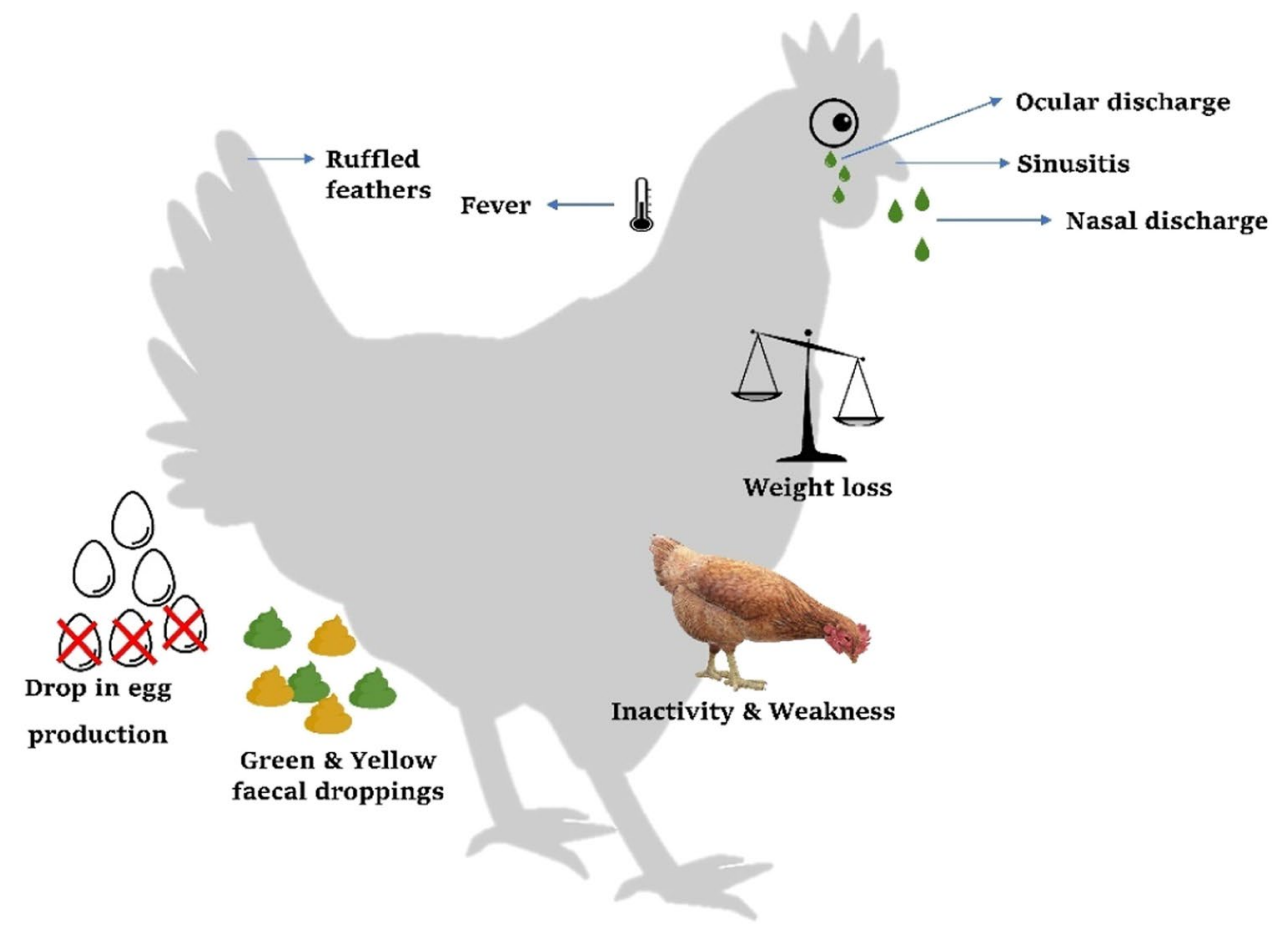

are reported from Psittaciformes (Feng et al. 2016). Humans are incidental and dead-end hosts. Disease in humans caused by three important modes of transmission: 1) inhalation, 2) direct contact (mouth-to-beak contact) and handling of plumage, 3) bite wounds (Harkinezhad et al. 2009). According to the $\mathrm{CDC}$, the incubation period is 5-14 days and may extend in humans. In humans, chlamydiosis not only targets the reproductive tract but also the respiratory tract causing interstitial pneumonia. Studies in trachoma patients showed the presence of $C$. psittaci, either alone or in combination with $C$. trachomatis (Dean et al. 2013). Symptoms in humans include fever, chills, headache, myalgia, and malaise with or without respiratory symptoms. Other organs may also be affected and may cause endocarditis, myocarditis hepatitis, arthritis, conjunctivitis, and encephalitis (Fig. 4).

The worldwide prevalence of human ornithosis infection is low. A study conducted in Germany based on realtime PCR analysis detected a higher percentage of patients positive for C. psittaci (2.1\%) infection than C. pneumoniae (1.4\%) (Dumke et al., 2015). Human infections from wild birds have not been widely documented. Shreds of evidence are available for the direct contact of wild bird feeders or contaminated faecal matter and indirect environmental contact of psittacine faeces as major zoonotic risk factors for contracting an infection (Rehn et al. 2013; Branley et al. 2016; Burnard and Polkinghorne 2016). Persons with pneumonia and a history of recent contact with a diseased or dead bird suspected of chlamydial infection should always be suspected for psittacosis. Human-to-human transmission also can occur but is exceptionally rare apart from a sporadically reported outbreak (CDC 2000; McGuigan et al. 2012; Wallensten et al. 2014).

\section{Birds + Equine = ornithosis in humans}

Zoonotic psittacosis originating from birds is usually underdiagnosed (Polkinghorne et al. 2020). Chlamydiosis in the equine will have different outcomes like bronchopneumonia accompanied by abortions in mares, hepatitis, fatal cases of encephalomyelitis, and polyarthritis in foals (Reinhold 2013). Transmission of $C$. psittaci from birds to the horse has been documented and abortion in mares is the common sign reported (Szeredi et al. 2005; Gough et al. 2020). Furthermore, the transmission of $C$. psittaci from equine to humans is not well characterized. Later, it was found that C. psittaci could be transmitted from equine to human as reported in 2014 in New South Wales, Australia, during an outbreak of respiratory illness in veterinary school students who handled the mare foetal membranes which delivered a premature foal. The detailed molecular epidemiological investigation revealed that infection of $C$. psittaci occurred from mare to humans with strain belonged to the most pathogenic groups of C. psittaci 6BC clade (Fig. 5) (Polkinghorne and Greub 2017; Chan et al. 2017; Jenkins et al. 2018). This spill-over infection evidence potentiated the environmental contamination with bird faeces and mammal to mammal transmission of $C$. psittaci and showed a new zoonotic risk of this chlamydial pathogen. Whether the problem is in some countries only or represents a worldwide issue has to be 
Fig. 4 Clinical manifestations in humans

\section{Severe cases}

Mild/moderate cases

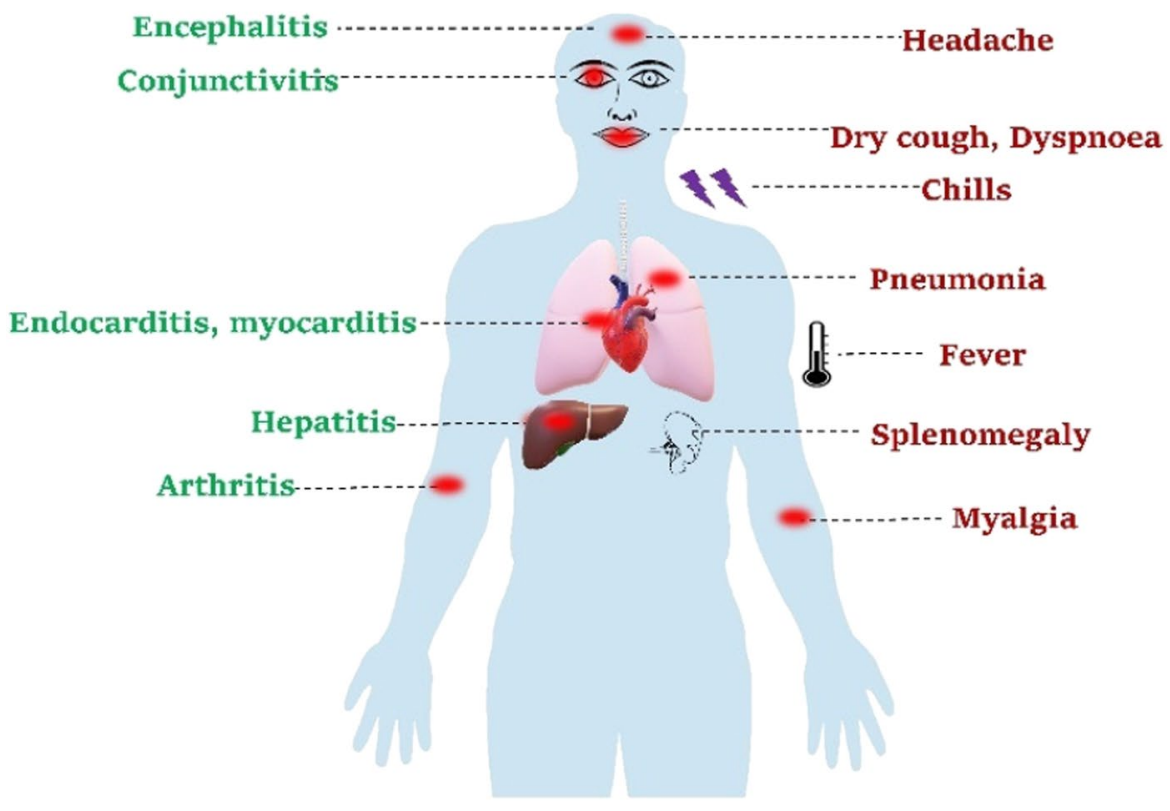

Fig. 5 Phylogeny relationship of $C$. psittaci based on MOMP gene sequence
Tree scale: $0.01 \longmapsto$

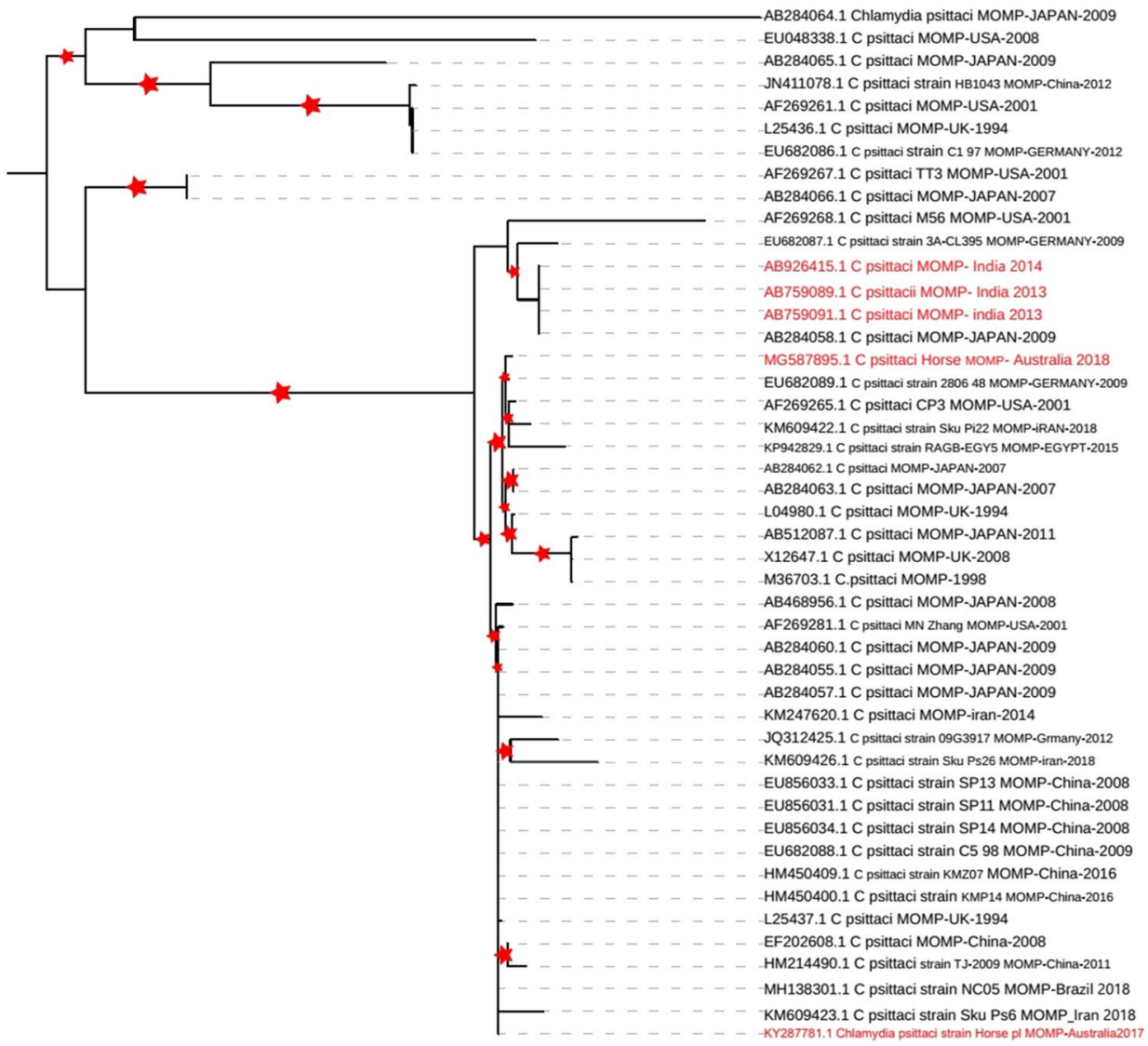


identified. The exact mechanism of transmission remains unclear, $C$. psittaci can develop stable infections in horses or only the result of sporadic 'spill-over' from a natural host (Jelocnik et al. 2018). Routine equine health surveillance of $C$. psittaci can help to understand the importance of this pathogen in horses. Serological diagnosis is the most practical and easy way to do this; however, this method is unvalued in chlamydiales because of strong cross-reactivity with other organisms. The zoonotic risk association of equine in C. psittaci infection should be taken into consideration with differential diagnosis of respiratory infections in human medicine.

\section{Immunity against chlamydia}

The innate immune system is an important key regulator in the control of chlamydial infection. Neutrophils are the first line of defence, and it utilizes reactive oxygen intermediate as well as some of the enzymes to eliminate the infection. Furthermore, dendritic cells and activated $\mathrm{T}$ cells also involved in an effective immune response. It also effectively activates the complement-mediated immune system against elementary bodies (Fedorko et al. 1987). Primarily, dendritic cells are involved in eliciting innate and adaptive immune system (Engering et al. 2002). Cytokines such as IL-12, IFN- $\gamma$, and TNF are secreted from various immune cells that effectively help to eradicate chlamydial infection. This bacterium has evolved to evade host immune response. Furthermore, cytokines from macrophages are downregulated during initial infection, and proper immune evasion mechanisms are not very well understood. Moreover, upregulation of replication, inclusion stabilization, protein processing, and molecular chaperone genes are imperative for the successful establishment and dissemination of the infection. Autophagy-mediated killing is also inhibited by preventing the lysosomal fusion to autophagosomes (Braukmann et al. 2012). It has also been proved that the organism has high antibacterial resistance apart from immune escaping mechanisms. To overcome this problem, many researchers developed the $\mathrm{T}$ cell-based vaccine which provides longer, effective cellular immunity and memory $\mathrm{T}$ cell response to equalise the humoral immunity failure (Karunakaran et al. 2015).

\section{New epidemiological dimensions}

Most of the countries usually report only a smaller number of cases, but experts believe that the disease is potentially under-reported and under-diagnosed. The persistence of chlamydia in hosts for an extended period as asymptomatic infections is the major problem for the under-reporting.
There are some hypothesized reasons for this persistence infections such as stress sensing and certain gene expressions of the organism. But the whole concept of persistence stage is still not understood clearly. Isolation of the bacteria from nest mite and avian lice show their possible role in the mechanical transmission (Eddie et al. 1962; Circella et al. 2011). The intestinal tract in some species appears to be the natural habitat for chlamydia. Rarely, birds may appear healthy and shed the bacteria in their droppings. Young birds tend to be more susceptible than older birds. In turkeys, genotype D causes severe respiratory outbreaks and high mortality. A high number of outbreaks in ducks were reported from China and Europe (Yin et al. 2013, 2015; Vorimore et al. 2015). It could be due to the handling of ducks or the presence of virulent strains. Concurrent infections or stress increase the severity of the disease. In 2013, an outbreak of psittacosis occurred in a group of 15 women aged between 42 and 67 who were involved in chicken gutting activities in France lead to the euthanization of all birds (Laroucau et al. 2015). The bacteria were identified in tumour conditions like ocular adnexal MALT (mucosa-associated lymphoid tissue) lymphomas (OAMLs), with high prevalence both in tumour tissue and peripheral blood mononuclear cells (Collina et al. 2012). C. psittaci seems to be present as a viable organism within lymphomatous tumours and has a preferred location as pathogen-exposed tissues. Chlamydia spp. are known to block the apoptotic process and also have mitogenic properties (Elwell et al. 2016). C. psittaci infections and presence of MALT lymphomas have strong correlations. The co-existence of both the infections is reported in Germany (about 47\%), the East Coast of the USA (about 35\%), and the Netherlands (about 29\%) (Chanudet et al. 2006).

A comprehensive and systematic analysis on the prevalence of $C$. psittaci in Ocular Adnexa Lymphoma specimens revealed high variability in different countries with higher prevalence in Italy and South Korea, and it is associated with MALT histotype (Travaglino et al. 2020). Recent reports of isolation of avian C. abortus strain from Eurasian Teal and polymerase chain reaction (PCR)-based confirmation in Polish wildfowl suggested that birds as a potential carrier for this zoonotic pathogen (SzymańskaCzerwińska et al. 2017a, b; Zaręba-Marchewka et al. 2019). Still, the geographical origin, infectivity, and pathogenicity are to be explored. Furthermore, Chlamydia buteonis was reclaimed by whole-genome sequencing in a red-tailed hawk, which is an intermediary between $C$. abortus and C. psittaci (Laroucau et al. 2019). Scientists are hypothesizing the emergence of any novel species that may be the result of recombination events from birds-ofprey/predators or other scavengers. Studies on C. psittaci in non-avian domestic animals and wildlife are less and suggested the mixed infections with other Chlamydial species (Fig. 6). Epidemiological findings speculated 
Fig. 6 Possible transmission routes of Chlamydia psittaci

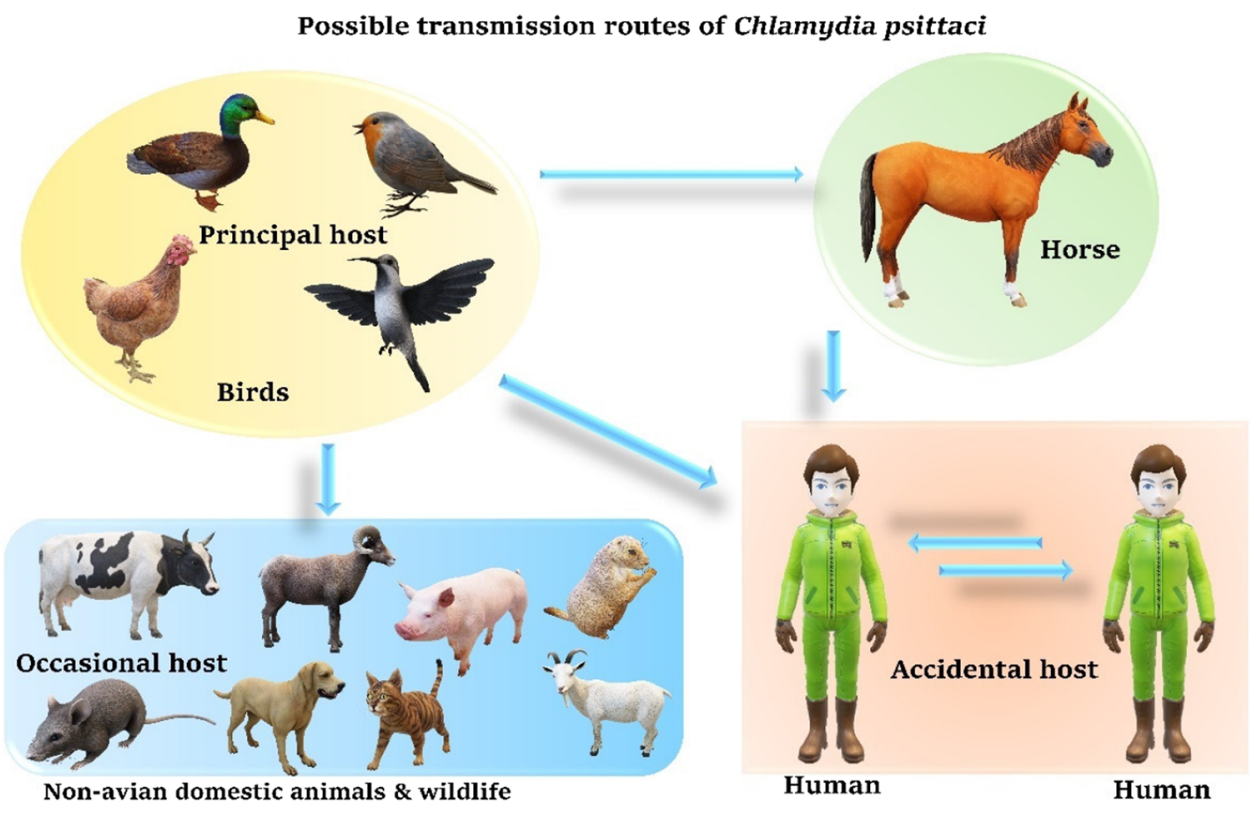

that the transfer of pathogen to non-avian species like cattle makes them less or no virulence, and some studies suggested that it may be due to less infectious dose. Coinfection of C. psittaci with other pathogens like avian influenza will trigger the infections by damaging macrophages (Chu et al. 2020).

\section{Occupational importance}

Psittacosis is an occupational health hazard for many people whose work brings them into contact with birds. It mainly includes bird fanciers, racing pigeons' keepers, pigeon fanciers, poultry production workers, diagnostic laboratories employees, domestic bird breeders, pet shop employees, poultry processing workers, veterinary clinics employees, public health inspectors, quarantine facilities employees, and exotic and bird dealers (Canadian Centre for Occupational Health \& Safety 2020). Reports of highrisk occupational exposure are mainly reported in bird fanciers and poultry industry workers but its importance is not relatively known as avian influenza. Multiple numbers of outbreaks in the 'poultry processing plants' (PPP) have been described in the past and the recent works of literature (Yung and Grayson 1988; Newman et al. 1992; Andersen and Vanrompay 2003; Verminnen et al. 2006; Laroucau et al. 2009b; Dickx et al. 2010). Most of the infections are asymptomatic in humans, and the outbreaks are sporadic, but there is a significant chance for morbidity and mortality. Hence, a thorough identification of those workers at risk is mandatory.

\section{Indian perspective}

In India, since the 1970s, seroepidemiological studies have been conducted both in southern and northern regions (especially from Himachal Pradesh). There is a lack of strain-level studies that could not able to give the exact picture of $C$. psittaci infection in India. In livestock, $C$. psittaci contributes to as many as $30.9 \%$ of abortion cases in sheep but comparatively less in goats (16.3\%). However, the association of chlamydial organisms with a respiratory infection is reported to be $18.5 \%$ in goats and $12.1 \%$ in sheep. Reports are supporting the important role played by C. psittaci in both respiratory and reproductive infections in sheep (Lenzko et al. 2011) and cattle (Reinhold et al. 2011). Bhardwaj et al. (2017) conducted a study, and they reported that only a few strains of $C$. psittaci are circulating in the region of Himachal Pradesh and apart from the respiratory problems, $C$. psittaci causes reproductive issues also in the livestock population. Sero assays conducted by antigens developed from the local strain of $C$. psittaci concluded that chlamydial infections are endemic amongst ruminants in five states (Himachal Pradesh, Punjab, Andhra Pradesh, Maharashtra, Jammu and Kashmir) of India, which may represent one of the causes of pneumonia, abortion, arthritis, enteritis, and other clinical outcomes (Chahota et al. 2015). Interestingly, $C$. psittaci has been isolated from the cervidae family in tissues and faeces samples in the North-Western Himalayan region (Rat$\tan$ et al. 2005). The prevalence study based on serological tests of $C$. psittaci in mules and horses in the area of Himachal Pradesh was observed to be $23.80 \%$ and $16.66 \%$, 
respectively. (Kumar et al. 2007). In the same region, an attempt was made to find out the prevalence of $C$. psittaci in feral birds such as Pigeons, Parrots, Crows, House sparrows, Doves, Indian mynahs, and nightingale. These birds are usually feed in and around the poultry farms and there is a high chance for transmission of chlamydiosis infection from the carrier or clinically sick feral birds to the poultry birds. In the study, they reported that a total of 16 isolates from intestinal contents/faecal swabs $(9 / 16)$ and pooled visceral organs $(7 / 16)$ has been isolated, from parrots $(26.31 \%)$, crows (18.18\%), and pigeons (16.36\%) (Chahota et al. 1997).

\section{Diagnosis}

Two methods are employed for the diagnosis of any disease: the first method is the detection of antigen and the second one is the detection of antibodies (Fig. 7). Higher the infective organism load combined with the acute nature of the disease help in higher chance of disease diagnosis (Sachse et al. 2009a, b). Standard diagnostic approaches for chlamydial species are rare because of their wide range of hosts, affecting multiple tissues/organs and complicated disease outcomes. Additionally, the intracellular lifestyle of Chlamydiae having considerable implications in diagnosis, because it cannot be grown on agar plates and need cell culture for isolation. In live birds, chlamydiosis is usually diagnosed by isolating $C$. psittaci from faeces, cloacal swabs, pharyngeal or nasal swabs, peritoneal exudate, or conjunctival scrapings. Cytological staining's like Giemsa, Gimenez, modified Gimenez, Ziehl-Neelsen, and Macchiavello stains of smears from exudates, impressions of tissues, and histological preparations will identify the infectious bodies (Campbell 2015) but none of the stains will specifically detect chlamydia so that losing its popularity.
Immunofluorescence and immunohistochemical staining for the identification of chlamydial organism in smears and sections are usually done with commercially available kits. C. psittaci is isolated in embryonated eggs, laboratory animals, or cell cultures of African green monkey (Vero), buffalo green monkey (BGM), McCoy, or L cells.

The isolation of the organism is no longer recommended for diagnosis because of its potential hazard to laboratory personnel, time-consuming, and laborious. The identification of the genetic material of the bacteria by nucleic acid amplification tests (NAAT) is highly recommended because of its quick, sensitive, and specific diagnosis. The techniques include conventional and realtime polymerase chain reaction, DNA microarray-based detection, and DNA sequencing. Quantification of the bacteria based on standard cell culture method is laborious, and now an alternative way of fluorescence resonance energy transfer (FRET) quantitative PCR showed 15 times more sensitive and accurate with Light $C y c l e r \circledR$ has been developed (Huang et al. 2001). Serological diagnosis includes methods like elementary body agglutination, antibody ELISA (detects IgA, IgG, IgM), modified complement fixation, direct and indirect immunofluorescence. The recent infection can be determined by the elementary body agglutination test, which detects IgM. Compared to agglutination methods, complement fixation methods are more sensitive. ELISA is highly sensitive when used with recombinant proteins and peptides as antigen targets (Verminnen et al. 2006; Sachse et al. 2009a, b). High antibody titres may persist after treatment and complicate the evaluation of subsequent tests (OIE 2018). The development of monoclonal antibodies (MAbs) against epitopes specific to the MOMP are exceptional tools for species, genus, or serovar-specific chlamydial diagnosis. On necropsy in birds, the gross post mortem lesions like splenomegaly, hepatomegaly, air sac changes, and fibrinous pericarditis
Fig. 7 Different diagnostic procedures available for avian chlamydiosis

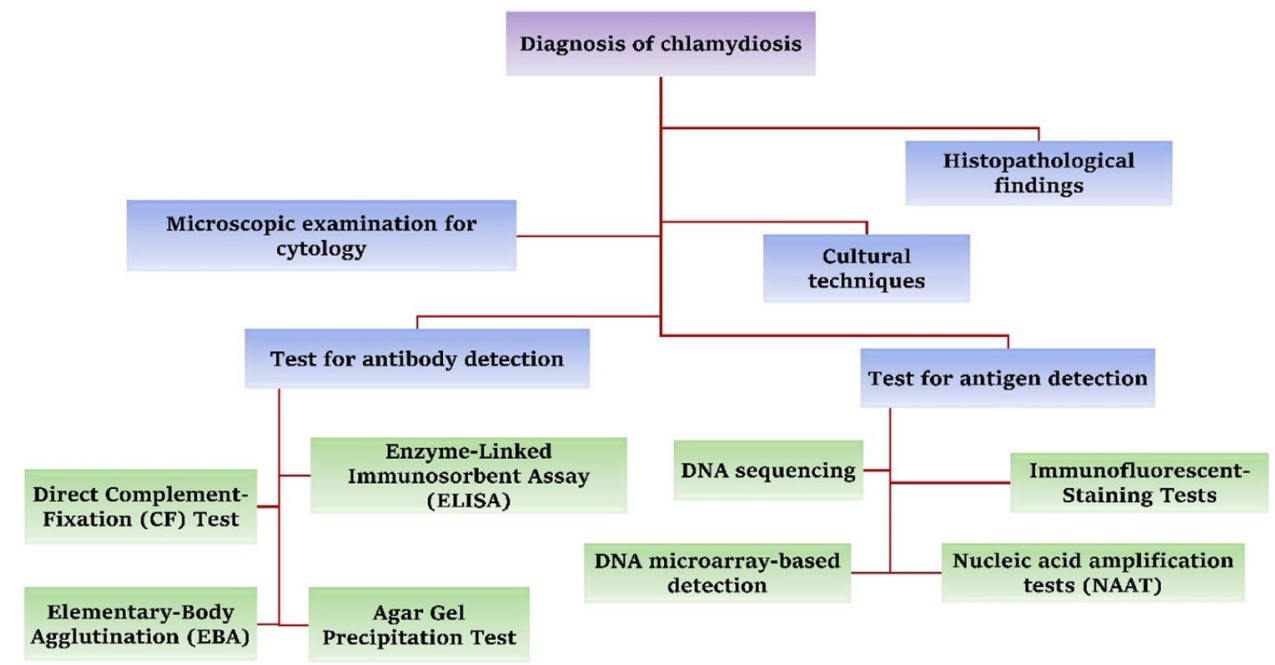


will be noticed, but not pathognomonic (Borel et al. 2018). Lesions are usually absent in latent infection.

There are no 'gold standard' tests to identify recent infections in humans. Usually, the laboratory diagnosis involves the use of microimmunofluorescence (MIF), CFT, and PCR. Previously testing paired sera for antibodies of Chlamydia by CFT was usually done, but seronegative in hospitalized patients were seen. Rapid identification of infection in humans was enabled by PCR and could identify the source by genotyping but has the disadvantage of high sensitivity only in the acute phase. In a practical scheme, a combination of a serologic and an antigen detection test like PCR is necessary to confirm chlamydiosis. As per the data available from USA CDC, the mortality rate psittacosis would be $<1 \%$ if diagnosed earlier and properly treated (CDC 2020). Genetically, variable genes (omp2 and ompA), conserved genes (16S rRNA, 23S rRNA), and some other targets, such as $\mathrm{KDO}$ transferase, GroEL chaperonin, and $o m p \mathrm{~B}$, are used for both analyzing species/strain level variations in field studies and detection of Chlamydiae (Bhardwaj et al. 2017).

\section{Treatment}

Chlamydial organisms are sensitive to different antibiotics like quinolones, tetracyclines, and macrolides but these antibiotics are not bactericidal (Table 3). So, there is a longtime persistence of antibiotics necessary to eliminate the pathogen from the body, and also, the effective immune response is helping to complete elimination (Rodolakis and Mohamad 2010). Treatment for avian chlamydiosis in animals is usually done with tetracycline (e.g., Doxycycline) or fluoroquinolones (e.g., enrofloxacin) either in oral (drinking water/feed) or parenteral (Intramuscular/ subcutaneous) routes (Bommana and Polkinghorne 2019). The drug of choice for chlamydiosis treatment are chlortetracycline and doxycycline, to eliminate clinical disease and faecal shedding. Chlortetracycline and doxycycline are effective against actively multiplying organisms. Infected birds should receive antibiotics in the cooked mash or pelleted feed continuously for at least 45 days, except in budgerigars (budgies or parakeets), where 30 days of treatment can be effective, but it may lead to subtherapeutic plasma concentrations (Vanrompay et al. 1995). Recent studies showed the effectiveness of 21-30 days of treatment but recommended the retest with PCR after 2-4 weeks of treatment. For persistant infections, experimental models suggest the usage of tetracycline or rifampicin for effective recovery. Oxytetracycline and doxycycline residues persist in laying hen eggs for 9 and 26 days, respectively, following 7 days of administration at $0.5 \mathrm{~g} / \mathrm{L}$. Resistance to antibiotics by $C$. psittaci was not reported, but some in vivo studies suggested the possibility of drug resistance strains (Prohl et al. 2015). In the Chlamydiae family, $C$. suis (recently identified as a zoonotic pathogen) is the only bacteria that showed the homotypic antibiotic resistance against tetracycline conferred by acquired resistance gene (tetA) through horizontal gene transfer (Joseph et al. 2016; Seth-Smith et al. 2017; Marti et al. 2018; Unterweger et al. 2020). The entry of persistence state by bacterium could be possible by treating the infection with Penicillin G, azithromycin which leads to chronic infections and antibiotic failure (Goellner et al. 2006; Zheng et al. 2015; Leonard et al. 2017; Xue et al. 2017).

Although antibiotic resistance is not reported in $C$. psittaci, the routine screening of field isolates, development of standardized antibiotic susceptibility assays, preand post-antibiotic treatment surveillance may assess the actual situation. Treatment in humans with tetracycline

Table 3 Drugs and treatment of Chlamydia Psittaci in different species

\begin{tabular}{|c|c|c|c|c|}
\hline Species & Antibiotic treatment & Dose & Route of administration & References \\
\hline Birds & $\begin{array}{l}\text { Chlortetracycline, Doxycy- } \\
\text { cline or enrofloxacin }\end{array}$ & $\begin{array}{l}500-5000 \mathrm{ppm} \text { accord- } \\
\text { ing to the species and } \\
\text { food in case of Chlortet- } \\
\text { racycline, } 1000 \mathrm{mg} / \mathrm{kg} \\
\text {-Doxycycline and } 250- \\
1000 \mathrm{ppm} \text { - enrofloxacin }\end{array}$ & $\begin{array}{l}\text { Oral administration through } \\
\text { feed or water and/or } \\
\text { Intramuscular injection. } \\
\text { Duration of treatment } \\
\text { varies }\end{array}$ & $\begin{array}{l}\text { Rodolakis and Mohamad } \\
2010\end{array}$ \\
\hline Cattle & Doxycycline & $\begin{array}{l}10 \mathrm{mg} \mathrm{kg} / \text { day twice daily } \\
\text { for } 14 \text { days }\end{array}$ & Orally, & Prohl et al. 2015 \\
\hline \multirow[t]{2}{*}{ Human } & Doxycycline,Minocycline & $100 \mathrm{mg}$ & $\begin{array}{l}\text { Orally or intravenously, two } \\
\text { times per day, } 7-10 \text { days }\end{array}$ & \multirow{2}{*}{$\begin{array}{l}\text { Beeckman and Vanrom- } \\
\text { pay 2009; Balsamo et al. } \\
2017\end{array}$} \\
\hline & Tetracycline & $500 \mathrm{mg}$ & $\begin{array}{l}\text { Orally, } 4 \text { times/day, } \\
7-10 \text { days }\end{array}$ & \\
\hline $\begin{array}{l}\text { Pregnant women and } \\
\text { children under age eight } \\
\text { years }\end{array}$ & $\begin{array}{l}\text { Azithromycin or Erythro- } \\
\text { mycin }\end{array}$ & $250-500 \mathrm{mg}$ & Orally, 7 days & Balsamo et al. 2017 \\
\hline
\end{tabular}


(preferably doxycycline, orally) should be continued for 10 to 14 days even after the control of fever (Beeckman and Vanrompay 2009). In children and pregnant women who are contraindicated to use tetracycline, a better alternative is macrolide antibiotics like erythromycin or azithromycin (dose: $250-500 \mathrm{mg}$, orally four times for 7 days) is used. The case fatality rate will be $1-5 \%$ with treatment and goes 10-20\% without treatment. Ovo transferrin showed a promising result as an alternative to antimicrobials in the reduction of clinical signs, lesions, excretion, and replication in experimentally infected SPF turkeys (Van Droogenbroeck et al. 2008, 2011).

\section{Prevention and control}

\section{Vaccination}

No commercial vaccine is available for avian chlamydiosis but attempts were made from 1978 by targeting whole-cell preparations and trailed in sheep, mice, and cats. The trials gave only partial protection, and so there is no well-established, commercialized, and effective vaccination (Nichols et al. 1978; Johnson and Hobson 1986; Greub 2010). In 1999, plasmid DNA vaccines for turkeys by expressing MOMP of serovar A and different routes of administration had been tried, but they failed to induce specific antigenic response (Vanrompay et al. 1999, 2001). Since 2000, only a limited number of trials were conducted with different antigenic targets but they gave only partial protection (Loots et al. 2006; Qiu et al. 2010; Liu et al. 2015; Liang et al. 2016; Ran et al. 2017). Though there are many antigenic targets, the development of whole-cell vaccines is giving promising results overall. A comprehensive review of chlamydial vaccine research by Phillips et al. (2019) revealed that a total of 220 vaccine trials had been conducted and it included 23 vaccine trials (10.5\%) in C. psittaci organism in a range of different hosts, including, mice, sheep, birds, Guinea pigs, and cats. There is a need for effective vaccines in humans because of its aerosolization potential to take measures to protect persons at high risk from becoming infected (Van Droogenbroeck et al. 2009; Halsby et al. 2014).

\section{Biosecurity and disinfection}

Due to the lack of effective vaccines, there is a need for risk reduction strategies to reduce human morbidity. Minimum biosecurity measures should be taken while handling pet birds and poultry (Balsamo et al. 2017). Since the infective material is airborne, persons should wear masks in poultry farms, and necropsy examination should be done with appropriate personal protective equipment. Aerosol monitoring can be done by a sensitive technique that uses PCR or culture to examine an air collection medium called ChlamyTrap, which will reduce the infection pressure (Van Droogenbroeck et al. 2009). Maintain accurate records of all bird-related transactions. Chlamydiae are usually susceptible to chemicals that will affect the lipid content or their cell wall integrity (Van Lent et al. 2016). Infectivity of the organism will be destroyed rapidly with the use of disinfections like 1:1000 dilution of quaternary ammonium compounds, 70\% isopropyl alcohol, 1\% Lysol, 1:100 dilution of household bleach, benzalkonium chloride, alcoholic iodine solution, $3 \%$ hydrogen peroxide, and silver nitrate. Applying a detergent antiseptic to wet the feathers of dead birds may reduce exposure to the bacterium. The organism may die at the temperature at $56^{\circ} \mathrm{c}$ for $5 \mathrm{~min}$ and destroyed in 3 min when exposed to ultraviolet light.

Worldwide, authorities like World Organisation of Animal Health (OIE) (https://www.oie.int/fileadmin/Home/eng/ Health_standards/tahm/2.03.01_AVIAN_CHLAMYD.pdf), European Union, US CDC (https://www.cdc.gov/pneum onia/atypical/psittacosis/about/prevention.html), National Association of State Public Health Veterinarians, Canadian Ministry of Health (https://www.rcdhu.com/wp-conte nt/uploads/2019/04/Mgmt-of-Avian-Chlamydiosis-Guide line_2019.pdf), and New South Wales Government (https:// www.health.nsw.gov.au/Infectious/controlguideline/Pages/ psittacosis.aspx) have issued standardized procedures and guidelines to control the $C$. psittaci infections. Specific standards for handling the pathogen in the laboratory are also available because of its biological risk. There are specific recommendations for the control of disease transmission between humans and birds like, risk education about psittacosis, risk reduction when caring for exposed or ill birds, accurate records maintenance of all bird-related transactions for a minimum of 1 year to support in source identification of infected birds and potentially exposed persons, selling or purchasing of birds with signs of avian chlamydiosis should be avoided, strict quarantine of exposed birds or newly acquired birds and isolation of birds with unknown status about $C$. psittaci should be tested before they are sold on consignment (Balsamo et al. 2017).

\section{Conclusion}

The surveillance system of the chlamydial pathogen was improved in the last two decades with development of technologies. It is necessary to have an awareness on the transmission and pathogenic potential of avian chlamydiosis in humans, which can guide surveillance efforts for public health authorities. Laboratories should include this pathogen in routine diagnosis of atypical pneumonia cases, which could likely increase cases. Though it is hardly followed 
in many situations, One Health partnership between human and veterinary stakeholders will be the vanguard of efforts to answer these questions for $C$. psittaci and other zoonotic agents. There is a need for better serological testing methods to use in epidemiological studies and explore the different transmission pathways, including equine to human transmission. Improvement in the diagnostic techniques would allow for better public health risk characterization of $C$. psittaci transmission especially from horses to humans and assist to obtain a better understanding of the comprehensive spectrum of disease. Currently, tests on nucleic acid amplification are considered state-of-the-art methods to diagnose chlamydial infections in animals and humans due to their sensitivity and specificity compared with other tests. Studies to identify the zoonotic links from wild birds, poultry farms, and slaughterhouses could be beneficial to public health.

Acknowledgements All the listed author(s) are thankful to their representative universities/institutes for providing the related support to compile this work.

Author contribution RK, SA, and KK conducted the literature search and interpreted the relevant literature; RK, SA, KK, and MA substantially contributed to the conception and design of the article; RK and BD prepared the figures and tables; RK, SA, KK, MA, and BD drafted the manuscript; KK and MA critically revised the work. All authors read and approved the manuscript.

Data availability Not applicable.

\section{Declarations}

Ethics approval Not applicable.

Consent to participate All the authors consent to participate in publication.

Consent for publication All the authors consent to publish the manuscript.

Competing interests The authors declare no competing interests.

\section{References}

Andersen, A.A., 1991. Serotyping of Chlamydia psittaci isolates using serovar-specific monoclonal antibodies with the micro immunofluorescence test, Journal of Clinical Microbiology, 29, 707-711.

Andersen, A. and Vanrompay, D., 2003. Avian chlamydiosis (Psittacosis, ornithosis). In: Saif Y, Barnes H, Fadly A, Glisson J, McDougald L and Swayne D, editors. Diseases of poultry. Ames, IA: Iowa State Press. 863-79, ISBN 0-8138-0423-X.

Arenas-Valls, N., Chacon, S., Perez, A. and Del Pozo, R., 2017. Atypical Chlamydia psittaci pneumonia. Four related cases, Archivos de Bronconeumología, 53(5), 277-279.

Arnaud, J. and Van Wettere, 2020. Avian Chlamydiosis (Psittacosis, Ornithosis, Parrot Fever). https://www.merckvetmanual.com/ poultry/avian-chlamydiosis/avian-chlamydiosis.
Balsamo, G., Maxted, A.M., Midla, J.W., Murphy, J.M., Wohrle, R., Edling. T.M., Fish, P.H., Flammer, K., Hyde, D., Kutty, P.K., Kobayashi, M., Helm, B., Oiulfstad, B., Ritchie, B.W., Stobierski, M.G., Ehnert, K. and Tully, T.N., 2017. Compendium of Measures to Control Chlamydia psittaci Infection Among Humans (Psittacosis) and Pet Birds (Avian Chlamydiosis), Journal of Avian Medicine and Surgery, 31(3), 262-282. (For table and text)

Bedson, S.P. and Bland, J.O.W., 1932. A morphological study of psittacosis virus, with the description of a developmental cycle, British Journal of Experimental Pathology, 13, 461-6.

Bedson, S.P., Western, G.T. and Simpson, S.L., 1930. Observations on the ethiology of psittacosis, Lancet 1, 235-236.

Beeckman, D.S.A. and Vanrompay, D.C.G., 2009. Zoonotic Chlamydophila psittaci infections from a clinical perspective, Clinical Microbiology and Infection, 15(1), 11-17.

Belmas, S. Viaie y aventuras en el nuevo mundo. Madrid, 1714, 61.

Berk, Y., Klaassen, C.H.W., Mouton J.W. and Meis J.F.G.M., 2008. An outbreak of psittacosis in a bird-fanciers fair in the Netherlands (Een uitbraak van psittacose na een vogelbeurs) Nederlands Tijdschrift voor Geneeskunde, 152(34), 1889-1892.

Bhardwaj, B., Chahota, R., Gupta, S., Malik, P. and Sharma, M., 2017. Identification of chlamydial strains causing abortions and pneumonia in sheep and goat flocks during trans Himalayan seasonal migration in the northern region of India, Veterinarski arhiv, 87(2), 151-170.

Bommana, S. and Polkinghorne, A., 2019. Antimicrobial Control of Chlamydial Infections in Animals: Current Practices and Issues, Frontiers in microbiology, 10, 113.

Borel, N., Polkinghorne, A. and Pospischil, A., 2018. A review on chlamydial diseases in animals: still a challenge for pathologists? Veterinary pathology, 55(3), 374-390.

Branley, J., Bachmann, N.L., Jelocnik, M., Myers, G.S. and Polkinghorne, A., 2016. Australian human and parrot Chlamydia psittaci strains cluster within the highly virulent $6 \mathrm{BC}$ clade of this important zoonotic pathogen, Scientific reports, 6(1), 1-8.

Braukmann, M., Sachse, K., Jacobsen, I.D., Westermann, M., Menge, C., Saluz, H.P. and Berndt, A., 2012. Distinct intensity of hostpathogen interactions in Chlamydia psittaci-and Chlamydia abortus-infected chicken embryos, Infection and immunity, 80(9), 2976-2988

Burnard, D. and Polkinghorne, A., 2016. Chlamydial infections in wildlife-conservation threats and/or reservoirs of 'spillover'infections? Veterinary microbiology, 196, 78-84.

Campbell, T.W., 2015. Normal avian cytology. In: Exotic Animal Hematology and Cytology. 4th edition. Terry W. Campbell, ed. Wiley-Blackwell, Oxford, 219-227.

Canadian Centre for Occupational Health \& Safety. 2020. Retrieved from: https://www.ccohs.ca/oshanswers/diseases/psittacosis.html

CDC (Centers for Disease Control and Prevention)., 2000. Compendium of measures to control Chlamydia psittaci infection among humans (psittacosis) and pet birds (avian chlamydiosis), MMWR. Recommendations and reports, 49(RR-8), 3-17.

CDC (Centers for disease control and prevention), 2020. Psittacosis. Clinical Features and Complications Retrieved from: https:// www.cdc.gov/pneumonia/atypical/psittacosis/hcp/clinical-featu rescomplications.html (Accessed on 01.06.2020).

Chahota, R., Gupta, S., Bhardwaj, B., Malik, P., Verma, S. and Sharma, A. M., 2015. Seroprevalence studies on animal chlamydiosis amongst ruminants in five states of India, Veterinary world, $8(1), 72-75$.

Chahota, Rajesh, Katoch, R.C. and Batta, M.K., 1997. Prevalence of Chlamydia psittaci among feral birds in Himachal Pradesh, Indian Journal Of Animal Research, 12, 89-94.

Chan, J., Doyle, B., Branley, J., Sheppeard, V., Gabor, M., Viney, K., Quinn, H., Janover, O., McCready, M. and Heller, J., 2017. An 
outbreak of psittacosis at a veterinary school demonstrating a novel source of infection, One health, 3, 29-33.

Chanudet, E., Zhou, Y., Bacon, C.M., Wotherspoon, A.C., MüllerHermelink, H.K., Adam, P., Dong, H.Y., De Jong, D., Li, Y., Wei, R. and Gong, X., 2006. Chlamydia psittaci is variably associated with ocular adnexal MALT lymphoma in different geographical regions, The Journal of Pathology: A Journal of the Pathological Society of Great Britain and Ireland, 209(3), 344-351.

Cheong, H.C., Lee, C.Y.Q., Cheok, Y.Y., Tan, G.M.Y., Looi, C.Y. and Wong, W.F., 2019. Chlamydiaceae: diseases in primary hosts and zoonosis, Microorganisms, 7(5), 146.

Chu, J., Guo, Y., Xu, G., Zhang, Q., Zuo, Z., Li, Q., Wang, Y. and He, C., 2020. Chlamydia psittaci Triggers the Invasion of H9N2 Avian Influenza Virus by Impairing the Functions of Chicken Macrophages, Animals, 10(4), 722.

Circella, E., Pugliese, N., Todisco, G., Cafiero, M.A., Sparagano, O.A.E. and Camarda, A., 2011. Chlamydia psittaci infection in canaries heavily infested by Dermanyssus gallinae, Experimental and applied acarology, 55(4), 329-338.

Collina, F., De Chiara, A., De Renzo, A., De Rosa, G., Botti, G. and Franco, R., 2012. Chlamydia psittaci in ocular adnexa MALT lymphoma: a possible role in lymphomagenesis and a different geographical distribution, Infectious agents and cancer, 7(1), $1-11$.

Costerton, J.W., Poffenroth, L., Wilt, J.C. and Kordova, N., 1976. Ultrastructural studies of the nucleoids of the pleomorphic forms of Chlamydia psittaci 6BC: a comparison with bacteria, Canadian Journal of Microbiology, 22, 16-28.

Dean, D., Rothschild, J., Ruettger, A., Kandel, R.P. and Sachse, K., 2013. Zoonotic Chlamydiaceae species associated with trachoma, Nepal, Emerging infectious diseases, 19(12), 1948.

Dickx, V., Geens, T., Deschuyffeleer, T., Tyberghien, L., Harkinezhad, T., Beeckman, D. S. A., Braeckman, L. and Vanrompay, D., 2010. Chlamydophila psittaci zoonotic risk assessment in a chicken and turkey slaughterhouse. Journal of clinical microbiology, 48(9), 3244-3250.

Dumke, R., Schnee, C., Pletz, M.W., Rupp, J., Jacobs, E., Sachse, K., Rohde, G. and Capnetz Study Group, 2015. Mycoplasma pneumoniae and Chlamydia spp. infection in community-acquired pneumonia, Germany, 2011-2012, Emerging infectious diseases, 21(3), 426.

Eddie, B., Meyer, K.F., Lambrecht, F.L. and Furman, D.P., 1962. Isolation of ornithosis bedsoniae from mites collected in turkey quarters and from chicken lice, The Journal of infectious diseases, 231-237.

Elwell, C., Mirrashidi, K. and Engel, J., 2016. Chlamydia cell biology and pathogenesis, Nature Reviews Microbiology, 14(6), 385-400.

Engering, A., Geijtenbeek, T.B., van Vliet, S.J., Wijers, M., van Liempt, E., Demaurex, N., Lanzavecchia, A., Fransen, J., Figdor, C.G., Piguet, V. and van Kooyk, Y., 2002. The dendritic cell-specific adhesion receptor DC-SIGN internalizes antigen for presentation to T cells, The Journal of Immunology, 168(5), 2118-2126.

European Commission, 2002. Avian chlamydiosis as a zoonotic disease and risk reduction strategies, Science Communications Animal Health Animal Welfare, 26.

Everett, K.D., Bush, R.M. and Andersen, A.A., 1999a. Emended description of the order Chlamydiales, proposal of Parachlamydiaceae fam. nov. and Simkaniaceae fam. nov., each containing one monotypic genus, revised taxonomy of the family Chlamydiaceae, including a new genus and five new species, and standards for the identification of organisms, International Journal of Systematic Bacteriology, 2, 415-40.

Everett, K.D.E., Hornung, L.J. and Andersen, A.A., 1999b. Rapid detection of the Chlamydiaceae and other families in the order
Chlamydiales: three PCR tests, Journal of Clinical Microbiology, 37, 575-580.

Fedorko, D.P., Clark, R.B., Nachamkin, I. and Dalton, H.P., 1987. Complement dependent in vitro neutralization of Chlamydia trachomatis by a subspecies-specific monoclonal antibody, Medical microbiology and immunology, 176(4), 225-228.

Feng, Y., Feng, Y.M., Zhang, Z.H., Wu, S.X., Zhong, D.B. and Liu, C.J., 2016. Prevalence and genotype of Chlamydia psittaci in faecal samples of birds from zoos and pet markets in Kunming, Yunnan, China, Journal of Zhejiang University-SCIENCE B, 17(4), 311-316.

Floriano, A.M., Rigamonti, S., Comandatore, F., Scaltriti, E., Longbottom, D., Livingstone, M., Laroucau, K., Gaffuri, A., Pongolini, S., Magnino, S. and Vicari, N., 2020. Complete Genome Sequence of Chlamydia avium PV 4360/2, Isolated from a Feral Pigeon in Italy, Microbiology Resource Announcements, 9(16).

Gaede, W., Reckling, K.F., Dresenkamp, B., Kenklies, S., Schubert, E., Noack, U., Irmscher, H.M., Ludwig, C., Hotzel, H. and Sachse, K., 2008. Chlamydophila psittaci infections in humans during an outbreak of psittacosis from poultry in Germany, Zoonoses and Public Health, 55(4), 184-188.

Goellner, S., Schubert, E., Liebler-Tenorio, E., Hotzel, H., Saluz, H.P. and Sachse, K., 2006. Transcriptional response patterns of Chlamydophila psittaci in different in vitro models of persistent infection, Infection and immunity, 74(8), 4801-4808.

Gough, S.L., Carrick, J., Raidal, S.L., Keane, S., Collins, N., Cudmore, L., Russell, C.M., Raidal, S. and Hughes, K.J., 2020. Chlamydia psittaci infection as a cause of respiratory disease in neonatal foals. Equine Veterinary Journal, 52(2), 244-249.

Greub, G., 2010. International Committee on Systematics of Prokaryotes Subcommittee on the taxonomy of the Chlamydiae: minutes of the inaugural closed meeting, 21 March 2009, Little Rock, AR, USA, International journal of systematic and evolutionary microbiology, 60(11), 2691-2693.

Grinblat-Huse, V., Drabek, E.F., Creasy, H.H., Daugherty, S.C., Jones, K.M., Santana-Cruz, I., Tallon, L.J., Read, T.D., Hatch, T.P., Bavoil, P. and Myers, G.S., 2011. Genome sequences of the zoonotic pathogens Chlamydia psittaci 6BC and Cal10, Journal of bacteriology, 193(15), 4039-4040.

Guo, W., Li, J., Kaltenboeck, B., Gong, J., Fan, W. and Wang, C., 2016. Chlamydia gallinacea, not C. psittaci, is the endemic chlamydial species in chicken (Gallus gallus), Scientific reports, 6(1), 1-10.

Halsby, K.D., Walsh, A.L., Campbell, C., Hewitt, K. and Morgan, D., 2014. Healthy animals, healthy people: zoonosis risk from animal contact in pet shops, a systematic review of the literature, PLoS One, 9(2), e89309.

Harkinezhad, T., Geens, T. and Vanrompay, D., 2009. Chlamydophila psittaci infections in birds: A review with emphasis on zoonotic consequences, Veterinary Microbiology, 135, 68-77.

Herrmann, B., Pettersson, B., Everett, K.D., Mikkelsen, N.E. and Kirsebom, L.A., 2000. Characterization of the rnpB gene and RNase P RNA in the order Chlamydiales, International Journal of Systematic and Evolutionary Microbiology, 1, 149-158.

Hogerwerf, L., De Gier, B., Baan, B. and Van Der Hoek, W., 2017. Chlamydia psittaci (psittacosis) as a cause of communityacquired pneumonia: a systematic review and meta-analysis, Epidemiology \& Infection, 145(15), 3096-3105.

Hogerwerf, L., Roof, I., de Jong, M.J., Dijkstra, F. and van der Hoek, W., 2020. Animal sources for zoonotic transmission of psittacosis: a systematic review, BMC infectious diseases, 20(1), 1-14.

Horn M. Class I. Chlamydiia class. nov. In: Krieg NR, Staley JT, Brown DR, Hedlund BP, Paster BJ, Ward NL, Ludwig W, Whitman WB (eds), Bergey's Manual of Systematic Bacteriology, 2nd Edn, Vol. 4, Springer, New York, 2010, p. 844.

Huang, J., DeGraves, F.J., Gao, D., Feng, P., Schlapp, T. and Kaltenboeck, B., 2001. Quantitative detection of Chlamydia spp. by 
fluorescent PCR in the LightCycler®, BioTechniques, 30(1), $150-157$.

Isaksson, J., Christerson, L., Blomqvist, M., Wille, M., Alladio, L.A., Sachse, K., Olsen, B., González-Acuña, D. and Herrmann, B., 2015. Chlamydiaceae-like bacterium, but no Chlamydia psittaci, in sea birds from Antarctica, Polar Biology, 38(11), 1931-1936.

Ito, I., Ishida, T., Mishima, M., Osawa, M., Arita, M., Hashimoto, T. and Kishimoto, T., 2002. Familial cases of psittacosis: possible person-to-person transmission, Internal medicine, 41(7), 580-583.

Jelocnik, M., Jenkins, C., O'Rourke, B., Barnwell, J. and Polkinghorne, A., 2018. Molecular evidence to suggest pigeon-type Chlamydia psittaci in association with an equine foal loss, Transboundary and emerging diseases, 65(3), 911-915.

Jenkins, C., Jelocnik, M., Micallef, M.L., Galea, F., Taylor-Brown, A., Bogema, D.R., Liu, M., O’Rourke, B., Chicken, C., Carrick, J. and Polkinghorne, A., 2018. An epizootic of Chlamydia psittaci equine reproductive loss associated with suspected spillover from native Australian parrots, Emerging microbes and infections, 7(1), 1-13.

Johnson, F.W.A. and Hobson, D., 1986. Intracerebral infection of mice with ovine strains of Chlamydia psittaci: an animal screening test for the assay of vaccines. Journal of comparative pathology, 96(5), 497-505.

Joseph, S.J., Marti, H., Didelot, X., Read, T.D. and Dean, D., 2016. Tetracycline selective pressure and homologous recombination shape the evolution of Chlamydia suis: a recently identified zoonotic pathogen, Genome biology and evolution, 8(8), 2613-2623.

Kaleta, E.F. and Taday, E.M., 2003. Avian host range of Chlamydophila spp. based on isolation, antigen detection and serology, Avian pathology, 32(5), 435-462.

Karunakaran, K., Subbarayal, P., Vollmuth, N. and Rudel, T., 2015. Chlamydia-infected cells shed Gp 96 to prevent chlamydial reinfection, Molecular Microbiology, 98(4), 694-711.

Knittler, M.R. and Sachse, K., 2015. Chlamydia psittaci: update on an underestimated zoonotic agent. Pathogens and disease, 73(1), 1-15.

Konrad Sachse, Evangelia Vretou, Morag Livingstone, Nicole Borel, Andreas Pospischil, and David Longbottom, 2009. Recent developments in the laboratory diagnosis of chlamydial infections, Veterinary Microbiology, 135, 2-21.

Krawiec, M., Piasecki, T. and Wieliczko, A., 2015. Prevalence of Chlamydia psittaci and other Chlamydia species in wild birds in Poland, Vector-borne and zoonotic diseases, 15(11), 652-655.

Kumar, R., Sharma, M., Katoch, V., Dhar, P., Thakur, A. and Gandhi, A., 2007. Observations on chlamydiosis and brucellosis in Spiti poines of Himachal Pradesh, CENTAUR-MADRAS-, 23(4), 70.

Laroucau, K., Aaziz, R., Meurice, L., Servas, V., Chossat, I., Royer, H., De Barbeyrac, B., Vaillant, V., Moyen, J.L., Meziani, F. and Sachse, K., 2015. Outbreak of psittacosis in a group of women exposed to Chlamydia psittaci-infected chickens, Eurosurveillance, 20(24), 21155.

Laroucau, K., de Barbeyrac, B., Vorimore, F., Clerc, M., Bertin, C., Harkinezhad, T., Verminnen, K., Obeniche, F., Capek, I., Bébéar, C. and Durand, B., 2009a. Chlamydial infections in duck farms associated with human cases of psittacosis in France, Veterinary microbiology, 135(1-2), 82-89.

Laroucau, K., Vorimore, F., Aaziz, R., Berndt, A., Schubert, E. and Sachse, K., 2009b. Isolation of a new chlamydial agent from infected domestic poultry coincided with cases of atypical pneumonia among slaughterhouse workers in France, Infection, Genetics and Evolution, 9(6), 1240-1247.

Laroucau, K., Vorimore, F., Aaziz, R., Solmonson, L., Hsia, R.C., Bavoil, P.M., Fach, P., Hölzer, M., Wuenschmann, A. and Sachse, K., 2019. Chlamydia buteonis, a new Chlamydia species isolated from a red-shouldered hawk, Systematic and applied microbiology, 42(5), 125997.

Lenzko, H., Moog, U., Henning, K., Lederbach, R., Diller, R., Menge, C., Sachse, K. and Sprague, L.D., 2011. High frequency of chlamydial co-infections in clinically healthy sheep flocks, BMC veterinary research, 7(1), 1-13.

Leonard, C.A., Schoborg, R.V. and Borel, N., 2017. Productive and penicillin-stressed Chlamydia pecorum infection induces nuclear factor kappa B activation and interleukin-6 secretion in vitro, Frontiers in cellular and infection microbiology, 7 , 180.

Li, J., Guo, W., Kaltenboeck, B., Sachse, K., Yang, Y., Lu, G., Zhang, J., Luan, L., You, J., Huang, K. and Qiu, H., 2016. Chlamydia pecorum is the endemic intestinal species in cattle while $\mathrm{C}$. gallinacea, C. psittaci and C. pneumoniae associate with sporadic systemic infection, Veterinary microbiology, 193, 93-99.

Li, L., Luther, M., Macklin, K., Pugh, D., Li, J., Zhang, J., Roberts, J., Kaltenboeck, B. and Wang, C., 2017. Chlamydia gallinacea: a widespread emerging Chlamydia agent with zoonotic potential in backyard poultry, Epidemiology and Infection, 145(13), 2701-2703.

Li, Z., Liu, P., Hou, J., Xu, G., Zhang, J., Lei, Y., Lou, Z., Liang, L., Wen, Y. and Zhou, J., 2020. Detection of Chlamydia psittaci and Chlamydia ibidis in the Endangered Crested Ibis (Nipponia nippon), Epidemiology and Infection, 148.

Liang, M., Wen, Y., Ran, O., Chen, L., Wang, C., Li, L., Xie, Y., Zhang, Y., Chen, C. and Wu, Y., 2016. Protective immunity induced by recombinant protein CPSIT_p8 of Chlamydia psittaci, Applied microbiology and biotechnology, 100(14), 6385-6393.

Lin, W., Chen, T., Liao, L., Wang, Z., Xiao, J., Lu, J., Song, C., Qin, J., Chen, F., Chang, Y.F. and Xie, Q., 2019. A parrot-type Chlamydia psittaci strain is in association with egg production drop in laying ducks, Transboundary and emerging diseases, 66(5), 2002-2010.

Liu, S., Sun, W., Chu, J., Huang, X., Wu, Z., Yan, M., Zhang, Q., Zhao, P., Igietseme, J.U., Black, C.M. and He, C., 2015. Construction of recombinant HVT expressing PmpD, and immunological evaluation against Chlamydia psittaci and Marek's disease virus, PLoS One, 10(4), e0124992.

Loots, K., Vleugels, B., Ons, E., Vanrompay, D. and Goddeeris, B.M., 2006. Evaluation of the persistence and gene expression of an anti-Chlamydophila psittaci DNA vaccine in turkey muscle, BMC veterinary research, 2(1), 1-6.

Madani, S.A. and Peighambari, S.M., 2013. PCR-based diagnosis, molecular characterization and detection of atypical strains of avian Chlamydia psittaci in companion and wild birds, Avian Pathology, 42(1), 38-44.

Marti, H., Borel, N., Dean, D. and Leonard, C.A., 2018. Evaluating the antibiotic susceptibility of chlamydia-New approaches for in vitro assays, Frontiers in microbiology, 9, 1414.

Matsui, T., Nakashima, K., Ohyama, T., Kobayashi, J., Arima, Y., Kishimoto, T., Ogawa, M., Cai, Y., Shiga, S., Ando, S. and Kurane, I., 2008. An outbreak of psittacosis in a bird park in Japan, Epidemiology and Infection, 136(4), 492-495.

Matsumoto, A. and Manire, G.P., 1970. Electron microscopic observations on the fine structure of cell walls of Chlamydia psittaci, Journal of bacteriology, 104(3), 1332-1337.

Mattmann, P., Marti, H., Borel, N., Jelocnik, M., Albini, S. and Vogler, B.R., 2019. Chlamydiaceae in wild, feral and domestic pigeons in Switzerland and insight into population dynamics by Chlamydia psittaci multilocus sequence typing, PLoS One, 14(12), $\mathrm{e} 0226088$.

McGuigan, C.C., McIntyre, P.G. and Templeton, K., 2012. Psittacosis outbreak in Tayside, Scotland, December 2011 to February 2012, Eurosurveillance, 17(22), 20186. 
Meyer, K.F. and Eddie, B., 1933. Latent psittacosis infections in shell parrakeets, Proceedings of the Society for Experimental Biology and Medicine, 30(4), 484-488.

Mitura, A., Szymańska-Czerwińska, M., Niemczuk, K. and Anara, J., 2014. Chlamydia in birds-occurrence, new species and zoonotic potential-a review, Bulletin of the Veterinary Institute in Pulawy, 58(4), 503-506.

Morange, A., 1895. De la psittacose, ou infection speciale determine'e par des perruches. Thesis/Dissertation.

Newman, C.S.J., Palmer, S.R., Kirby, F.D. and Caul, E.O., 1992. A prolonged outbreak of ornithosis in duck processors, Epidemiology and Infection, 108(1), 203-210.

Nichols, R.L., Murray, E.S. and Nisson, P.E., 1978. Use of enteric vaccines in protection against chlamydial infections of the genital tract and the eye of guinea pigs, Journal of Infectious Diseases, 138(6), 742-746.

OIE, 2018. Terrestrial Manual, Avian Chlamydiosis.

Ornelas-Eusebio, E., Garcia-Espinosa, G., Vorimore, F., Aaziz, R., Durand, B., Laroucau, K. and Zanella, G., 2020. Cross-sectional study on Chlamydiaceae prevalence and associated risk factors on commercial and backyard poultry farms in Mexico, Preventive veterinary medicine, 176, 104922.

Phillips, S., Quigley, B.L., and Timms, P., 2019. Seventy years of Chlamydia vaccine research-limitations of the past and directions for the future, Frontiers in microbiology, 10, 70.

Polkinghorne, A. and Greub, G., 2017. A new equine and zoonotic threat emerges from an old avian pathogen, Chlamydia psittaci, Clinical Microbiology and Infection, 23(10), 693-694.

Polkinghorne, A., Weston, K.M. and Branley, J., 2020. Recent history of psittacosis in Australia: expanding our understanding of the epidemiology of this important globally distributed zoonotic disease, Internal Medicine Journal, 50(2), 246-249.

Pospischil, A., 2009. From disease to etiology: historical aspects of Chlamydia-related diseases in animals and humans, Drugs Today, 45, 141-146.

Prohl, A., Lohr, M., Ostermann, C., Liebler-Tenorio, E., Berndt, A., Schroedl, W., Rothe, M., Schubert, E., Sachse, K. and Reinhold, P., 2015. Enrofloxacin and macrolides alone or in combination with rifampicin as antimicrobial treatment in a bovine model of acute Chlamydia psittaci infection, PloS one, 10(3).

Qiu, C., Zhou, J., Cao, X.A., Lin, G., Zheng, F. and Gong, X., 2010. Immunization trials with an avian chlamydial MOMP gene recombinant adenovirus, Bioengineered Bugs, 1(4), 269-275.

Radomski, N., Einenkel, R., Müller, A. and Knittler, M.R., 2016. Chlamydia-host cell interaction not only from a bird's eye view: some lessons from Chlamydia psittaci, FEBS letters, 590(21), 3920-3940.

Ramsay, E.C., 2003. The psittacosis outbreak of 1929-1930, Journal of Avian Medicine and Surgery, 17(4), 235-237.

Ran, O., Liang, M., Yu, J., Yu, M., Song, Y. and Yimou, W., 2017. Recombinant protein CPSIT_0846 induces protective immunity against Chlamydia psittaci infection in BALB/c mice, Pathogens and disease, 75(3).

Rattan, S., Katoch, R.C., Sharma, M., Dhar, P., Chahota, R. and Singh, M., 2005. Isolation of Chlamydia psittaci from cervidae in northwestern himalayan region, Indian Journal of Comparative Microbiology, Immunology and Infectious Diseases, 26(2), 103-104.

Rehn, M., Ringberg, H., Runehagen, A., Herrmann, B., Olsen, B., Petersson, A.C., Hjertqvist, M., Kühlmann-Berenzon, S. and Wallensten, A., 2013. Unusual increase of psittacosis in southern Sweden linked to wild bird exposure, January to April 2013, Eurosurveillance, 18(19), 20478.

Reinhold, P., 2013. Overview of Chlamydiosis, Retreived from https:// www.msdvetmanual.com/generalized-conditions/chlamydiosis/ overview-of-chlamydiosis
Reinhold, P., Sachse, K. and Kaltenboeck, B., 2011. Chlamydiaceae in cattle: commensals, trigger organisms, or pathogens? The Veterinary Journal, 189(3), 257-267.

Ritter, J., 1879. Über pneumotyphus, eine hausepidemie in uster, Arch. klin. Med., 25, 53.

Robertson, T., Bibby, S., O'Rourke, D., Belfiore, T., Agnew-Crumpton, R. and Noormohammadi, A.H., 2010. Identification of chlamydial species in crocodiles and chickens by PCR-HRM curve analysis, Veterinary microbiology, 145(3-4), 373-379.

Rodolakis, A. and Mohamad, K.Y., 2010. Zoonotic potential of Chlamydophila, Veterinary microbiology, 140(3-4), 382-391.

Rotz, L.D., Khan, A.S., Lillibridge, S.R., Ostroff, S.M. and Hughes, J.M., 2002. Public health assessment of potential biological terrorism agents, Emerging infectious diseases, 8(2), 225.

Rybarczyk, J., Versteele, C., Lernout, T. and Vanrompay, D., 2020. Human psittacosis: a review with emphasis on surveillance in Belgium, Acta Clinica Belgica, 75(1), 42-48.

Sachse, K., Bavoil, P.M., Kaltenboeck, B., Stephens, R.S., Kuo, C.C., Rosselló-Móra, R. and Horn, M., 2015a. Emendation of the family Chlamydiaceae: proposal of a single genus, chlamydia, to include all currently recognized species, Systematic and applied microbiology, 38(2), 99-103.

Sachse, K., Laroucau, K. and Vanrompay, D., 2015b. Avian chlamydiosis, Current Clinical Microbiology Reports, 2(1), 10-21.

Sachse, K., Laroucau, K., Riege, K., Wehner, S., Dilcher, M., Creasy, H.H., Weidmann, M., Myers, G., Vorimore, F., Vicari, N. and Magnino, S., 2014. Evidence for the existence of two new members of the family Chlamydiaceae and proposal of Chlamydia avium sp. nov. and Chlamydia gallinacea sp. Nov., Systematic and applied microbiology, 37(2), 79-88.

Sachse, K., Vretou, E., Livingstone, M., Borel, N., Pospischil, A. and Longbottom, D., 2009. Recent developments in the laboratory diagnosis of chlamydial infections, Veterinary microbiology, 135(1-2), 2-21.

Seth-Smith, H.M., Wanninger, S., Bachmann, N., Marti, H., Qi, W., Donati, M., di Francesco, A., Polkinghorne, A. and Borel, N., 2017. The Chlamydia suis genome exhibits high levels of diversity, plasticity, and mobile antibiotic resistance: comparative genomics of a recent livestock cohort shows influence of treatment regimes, Genome biology and evolution, 9(3), 750-760.

Shivaprasad, H. L., Carnaccini, S., Bland, M., Aaziz, R., Moeller, R. and Laroucau, K., 2015. An Unusual Outbreak of Chlamydiosis in Commercial Turkeys Involving the Nasal Glands, Avian Diseases, 59(2), 315-322.

Szeredi, L., Hotzel, H. and Sachse, K., 2005. High prevalence of chlamydial (Chlamydophila psittaci) infection in fetal membranes of aborted equine fetuses, Veterinary research communications, 29(1), 37-49.

Szymańska-Czerwińska, M., Mitura, A., Niemczuk, K., Zaręba, K., Jodełko, A., Pluta, A., Scharf, S., Vitek, B., Aaziz, R., Vorimore, F. and Laroucau, K., 2017b. Dissemination and genetic diversity of chlamydial agents in Polish wildfowl: Isolation and molecular characterisation of avian Chlamydia abortus strains, PLoS One, 12(3).

Szymańska-Czerwińska, M., Mitura, A., Zaręba, K., Schnee, C., Koncicki, A. and Niemczuk, K., 2017a. Poultry in Poland as Chlamydiaceae carrier, Journal of veterinary research, 61(4), 411-419.

Taylor-Brown, A. and Polkinghorne, A., 2017. New and emerging chlamydial infections of creatures great and small, New microbes and new infections, 18, 28-33.

Travaglino, Antonio, Mirella Pace, Silvia Varricchio, Roberta Della Pepa, Adriana Iuliano, Marco Picardi, Fabrizio Pane, Stefania Staibano, and Massimo Mascolo, 2020. "Prevalence of Chlamydia psittaci, Chlamydia pneumoniae, and Chlamydia trachomatis Determined by Molecular Testing in Ocular Adnexa Lymphoma Specimens: A Systematic Review and 
Meta-Analysis.”, American Journal of Clinical Pathology, 153, 427-434.

Unterweger, C., Schwarz, L., Jelocnik, M., Borel, N., Brunthaler, R., Inic-Kanada, A. and Marti, H., 2020. Isolation of TetracyclineResistant Chlamydia suis from a Pig Herd Affected by Reproductive Disorders and Conjunctivitis, Antibiotics, 9(4), 187.

Van Droogenbroeck, C., Beeckman, D.S., Harkinezhad, T., Cox, E. and Vanrompay, D., 2008. Evaluation of the prophylactic use of ovotransferrin against chlamydiosis in SPF turkeys, Veterinary microbiology, 132(3-4), 372-378.

Van Droogenbroeck, C., Dossche, L., Wauman, T., Van Lent, S., Phan, T.T., Beeckman, D.S. and Vanrompay, D., 2011. Use of ovotransferrin as an antimicrobial in turkeys naturally infected with Chlamydia psittaci, avian metapneumovirus and Ornithobacterium rhinotracheale, Veterinary microbiology, 153(3-4), 257-263.

Van Droogenbroeck, C., Van Risseghem, M., Braeckman, L. and Vanrompay, D., 2009. Evaluation of bioaerosol sampling techniques for the detection of Chlamydophila psittaci in contaminated air, Veterinary microbiology, 135(1-2), 31-37.

Van Lent, S., De Vos W.H., Huot Creasy, H., Marques, P.X., Ravel, J., Vanrompay, D., Bavoil, P. and Hsia, R.C., 2016. Analysis of polymorphic membrane protein expression in cultured cells identifies PmpA and PmpH of Chlamydia psittaci as candidate factors in pathogenesis and immunity to infection, PLoS One. $15,11, \mathrm{e} 0162392$.

Vanrompay, D., 2020. Avian chlamydiosis, Diseases of poultry, 1086-1107.

Vanrompay, D., Andersen, A.A., Ducatelle, R. and Haesebrouck, F., 1993. Serotyping of European isolates of Chlamydia psittaci from poultry and other birds, Journal of clinical microbiology, 31(1), 134-137.

Vanrompay, D., Cox, E., Kaiser, P., Lawson, S., Van Loock, M., Volckaert, G. and Goddeeris, B., 2001. Protection of turkeys against Chlamydophila psittaci challenge by parenteral and mucosal inoculations and the effect of turkey interferon-gamma on genetic immunization, Immunology, 103, 106-112

Vanrompay, D., Cox, E., Vandenbussche, F., Volckaert, G. and Goddeeris, B., 1999. Protection of turkeys against Chlamydia psittaci challenge by gene gun-based DNA immunizations, Vaccine, 17 , 2628-2635.

Vanrompay, D., Ducatelle, R. and Haesebrouck, F., 1995. Chlamydia psittaci infections: a review with emphasis on avian chlamydiosis, Veterinary microbiology, 45(2-3), 93-119.

Verminnen, K., Van Loock, M., Hafez, H.M., Ducatelle, R., Haesebrouck, F. and Vanrompay, D., 2006. Evaluation of a recombinant enzyme-linked immunosorbent assay for detecting Chlamydophila psittaci antibodies in turkey sera, Veterinary research, 37(4), 623-632.

Vorimore, F., Hsia, R.C., Huot-Creasy, H., Bastian, S., Deruyter, L., Passet, A., Sachse, K., Bavoil, P., Myers, G. and Laroucau, K., 2013. Isolation of a new Chlamydia species from the feral sacred ibis (Threskiornis aethiopicus): Chlamydia ibidis, PLoS One, $8(9)$.

Vorimore, F., Thebault, A., Poisson, S., Cleva, D., Robineau, J., de Barbeyrac, B., Durand, B. and Laroucau, K., 2015. Chlamydia psittaci in ducks: a hidden health risk for poultry workers, Pathogens and disease, 73(1), 1-9.

Wallensten, A., Fredlund, H. and Runehagen, A., 2014. Multiple human-to-human transmission from a severe case of psittacosis, Sweden, January-February 2013, Eurosurveillance, 19(42), 20937.

Wang, X., Zhang, N.Z., Ma, C.F., Zhang, X.X., Zhao, Q. and Ni, H.B., 2018. Epidemiological investigation and genotype of Chlamydia exposure in pigeons in three provinces in northern China, Vectorborne and Zoonotic Diseases, 18(3), 181-184.

Weygaerde, Y.V., Versteele, C., Thijs, E., De Spiegeleer, A., Boelens, J., Vanrompay, D., Van Braeckel, E. and Vermaelen, K., 2018. An unusual presentation of a case of human psittacosis, Respiratory medicine case reports, 23, 138-142.

Xue, Y., Zheng, H., Mai, Z., Qin, X., Chen, W., Huang, T., Chen, D. and Zheng, L., 2017. An in vitro model of azithromycin-induced persistent Chlamydia trachomatis infection, FEMS microbiology letters, 364(14).

Yin, L., Kalmar, I.D., Boden, J. and Vanrompay, D., 2015. Chlamydia psittaci infections in Chinese poultry: a literature review, World's Poultry Science Journal, 71(3), 473-482.

Yin, L., Kalmar, I.D., Lagae, S., Vandendriessche, S., Vanderhaeghen, W., Butaye, P., Cox, E. and Vanrompay, D., 2013. Emerging Chlamydia psittaci infections in the chicken industry and pathology of Chlamydia psittaci genotype B and D strains in specific pathogen free chickens, Veterinary microbiology, 162(24), 740-749.

You, J., Wu, Y., Zhang, X., Wang, X., Gong, J., Zhao, Z., Zhang, J., Zhang, J., Sun, Z., Li, J. and Guo, W., 2019. Efficient fecal-oral and possible vertical, but not respiratory, transmission of emerging Chlamydia gallinacea in broilers, Veterinary microbiology, 230, 90-94.

Yung, A.P. and Grayson, M.L., 1988. Psittacosis-a review of 135 cases, Medical journal of Australia, 148(5), 228-233.

Zaręba-Marchewka, K., Szymańska-Czerwińska, M., Mitura, A. and Niemczuk, K., 2019. Draft genome sequence of avian Chlamydia abortus genotype G1 strain 15-70d24, isolated from Eurasian teal in Poland, Microbiology resource announcements, 8(33), e00658-19.

Zheng, H., Xue, Y., Bai, S., Qin, X., Lu, P. and Yang, B., 2015. Association of the in vitro susceptibility of clinical isolates of Chlamydia trachomatis with serovar and duration of antibiotic exposure, Sexually transmitted diseases, 42(3), 115-119.

Zocevic, A., Vorimore, F., Vicari, N., Gasparini, J., Jacquin, L., Sachse, K., Magnino, S. and Laroucau, K., 2013. A real-time PCR assay for the detection of atypical strains of Chlamydiaceae from pigeons, PloS one, 8(3), e58741.

Publisher's note Springer Nature remains neutral with regard to jurisdictional claims in published maps and institutional affiliations. 